\title{
Chemical characteristics of water-insoluble components in aeolian dust collected in China in spring 2002
}

\author{
Atsuyuki Ohta ${ }^{1}$, Renjian $Z_{\text {hang }}{ }^{2}$, Shigeru Terashima ${ }^{1}$, Yutaka Kanai ${ }^{3}$, \\ Hikari Kamioka ${ }^{3}$, Noboru Imai ${ }^{1}$, Yukihiro Matsuhisa ${ }^{1}$, Hiroshi Shimizu ${ }^{4}$, \\ Yoshio Takahashi ${ }^{4}$, Kenji Kai ${ }^{5}$, and Masahiko Hayashi ${ }^{6}$
}

\begin{abstract}
Atsuyuki Ohta, Renjian Zhang, Shigeru Terashima, Yutaka Kanai, Hikari Kamioka, Noboru Imai, Yukihiro Matsuhisa, Hiroshi Shimizu, Yoshio Takahashi, Kenji Kai and Masahiko Hayashi (2005) Chemical characteristics of water-insoluble components in aeolian dust collected in China in spring 2002. Bull. Geol. Surv. Japan, vol. 56 (7/8), 259-272, 5 figs, 1 appendix.
\end{abstract}

\begin{abstract}
Aeolian dust collected at three stations in China (Beijing, Qingdao, and Hefei) in spring 2002 has been analyzed and their chemical features have been thoroughly discussed. The mass concentrations of aeolian dust collected were high in coarse grains, and the distribution patterns against particle size were different among the sampling stations. When large-scale dust events were observed, the concentrations of suspended particle with a particle size over $2 \mu \mathrm{m}$ especially increased. The chemical compositions $\left(\mathrm{Al}_{2} \mathrm{O}_{3} \mathrm{Na}_{2} \mathrm{O}, \mathrm{P}_{2} \mathrm{O}_{5}\right.$, Total $\mathrm{Fe}_{2} \mathrm{O}_{3}, \mathrm{Rb}, \mathrm{Zr}$, and $\left.\mathrm{La}\right)$ of all but one aeolian dust sample were almost constant in coarse grains and quickly decreased below 1.1-2.1 $\mu \mathrm{m}$. This result suggests that the contribution of mineral aerosol to aeolian dust sharply decreased in fine grains. In the dust event of March at Beijing, however, these elemental concentrations were almost constant over the variations of particle size. This fact indicates that the large-scale dust event supplied a large amount of mineral aerosol even in fine grains. The elemental concentration ratios to $\mathrm{Al}_{2} \mathrm{O}_{3}$ were almost constant in coarse-medium grains, but suddenly increased below 1-2 $\mu \mathrm{m}$ : the mineralogical composition was homogenous in coarse-middle grains, but changed in fine grains. The grain-size distribution pattern of the elemental concentration ratio has no systematic variations with or without a dust event or among three sampling stations. Therefore, chemical features of aeolian dust coming from inland China and suspended particle accumulated around sampling locations are very similar. On the contrary, some heavy elements ( $\mathrm{Cr}, \mathrm{Ni}, \mathrm{Cu}, \mathrm{Zn}, \mathrm{Mo}, \mathrm{Cd}, \mathrm{Sb}, \mathrm{Sn}, \mathrm{Pb}$, and Bi) had different features from elements that originated form mineral aerosol such as $\mathrm{Al}_{2} \mathrm{O}_{3}$. The concentrations and metal $/ \mathrm{Al}_{2} \mathrm{O}_{3}$ ratios for these heavy metals increased with decreasing particle size. For example, the $\mathrm{Cu} / \mathrm{Al}_{2} \mathrm{O}_{3}$ and $\mathrm{Pb} / \mathrm{Al}_{2} \mathrm{O}_{3}$ ratios dramatically increased tenfold to hundredfold with decreasing particle size. These distribution patterns against the particle size suggest that anthropogenic materials were contaminated to finer grains.
\end{abstract}

Keywords: aeolian dust, water-insoluble components, grain-size distribution, mass concentration, chemical composition, Beijing, Hefei, Qingdao

\section{Introduction}

Atmospheric aerosols have serious effects to life, agriculture, and traffic, and heavily impact human health and the global climate. From the viewpoint of atmospheric pollution, the National Institute for Environmental Studies (2001) reported some observations on atmospheric aerosols in China. Zhang et al. (2002,
$2003 a, b)$ have studied the mass concentrations of total suspended particles and its chemical composition in Beijing for this purpose. These studies mainly targeted fine grains (below $2.5 \mu \mathrm{m}$ ), which have the most important effect on human health. Therefore, the investigation on the impact of aeolian dust on the climate is another important problem. The "Aeolian Dust Experiment on Climate Impact (ADEC)” project has

\footnotetext{
${ }^{1}$ Institute of Geology and Geoinformation, GSJ, AIST, Central 7 1-1-1 Higashi, Tsukuba, Ibaraki, 305-8567, Japan.

${ }^{2}$ Institute of Atmospheric Physics, Chinese Academy of Sciences, Beijing, 100029, P. R. China.

${ }^{3}$ Research Center for Deep Geological Environments, GSJ, AIST, Central 7 1-1-1 Higashi, Tsukuba, Ibaraki, 305-8567, Japan.

${ }^{4}$ Hiroshima University, 1-3-1 Kagamiyama, Higashi-Hiroshima, 739-8526, Japan.

${ }^{5}$ Nagoya University, Furo-cho, Chikusa-ku, Nagoya, 464-8601, Japan.

${ }^{6}$ Fukuoka University, 8-19-1 Nanakuma, Jonan-ku, Fukuoka, 814-0180, Japan.
} 


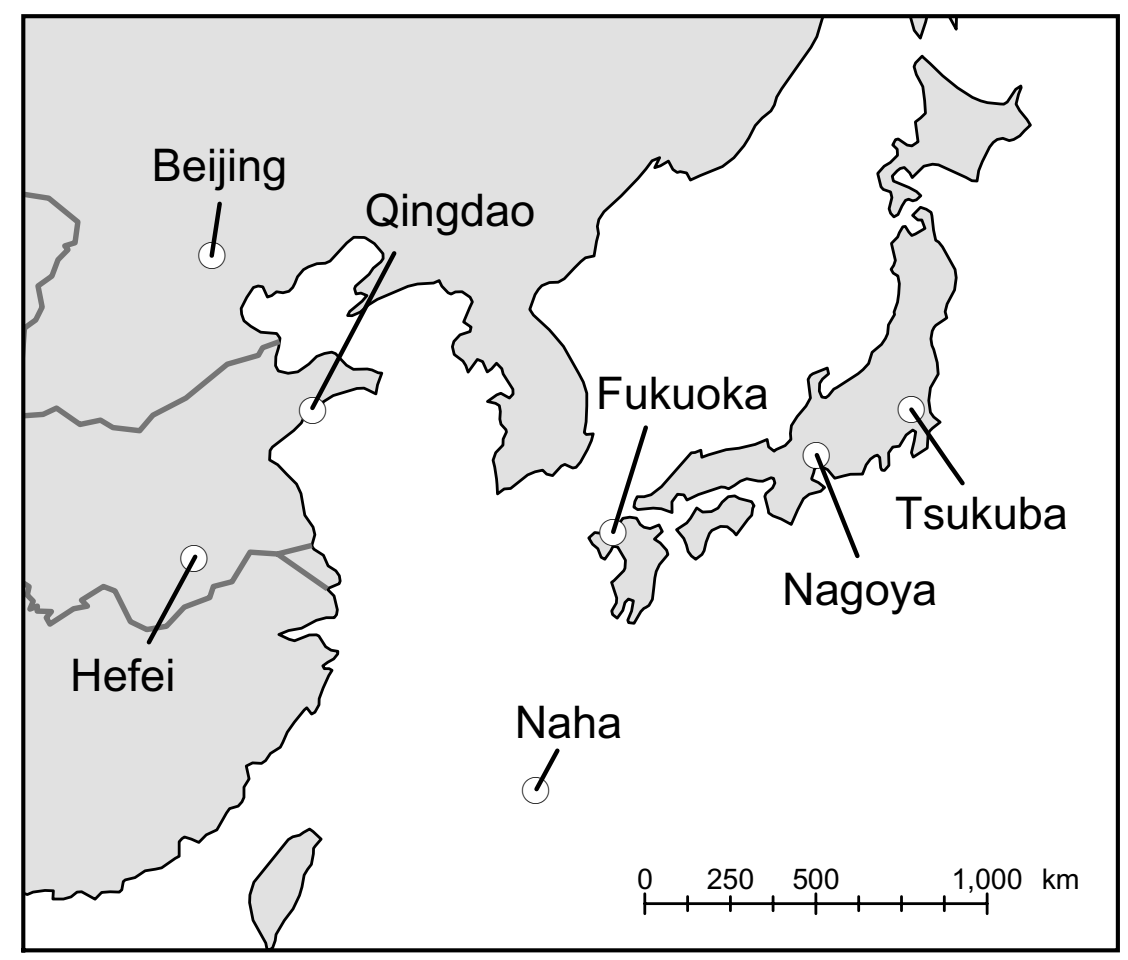

Fig. 1 Sampling locations in China and Japan for the ADEC project.

the above-mentioned goal and observed aeolian dust at several stations in China and Japan from April 2000 to March 2005. In ADEC project, the authors have tried to explain the physical and chemical characteristics and grain-size distribution of aeolian dust, which is transported from China to Japan. The dust samples were collected at three Chinese stations (Beijing, Qingdao, and Hefei) and four Japanese stations (Naha, Fukuoka, Nagoya, and Tsukuba) by using high and low volume air samplers (Fig. 1).

Our purpose is to explain the following three points; 1) the similarity and difference among sampling locations in Japan or China and influence of a dust event (Ohta et al., 2003), 2) the chemical compositional change during the transportation of aeolian dust from China (Beijing) to Japan (Ohta et al., 2004; 2005a), and 3 ) the seasonal variation of the chemical composition of aeolian dust at the Tsukuba station, Japan (Ohta et al., 2005b). In this paper, the authors focus on the data at three Chinese stations in spring 2002, which have not been reported yet. Beijing and Qingdao were hit by aeolian dust coming from southern Mongolia, western Inner Mongolia, and inland China (Takla Makan Desert and Talim Basin), but the dust event was scarcely observed in Hefei. The samples collected at Hefei are useful to examine chemical and physical property of aeolian dust and those at Beijing and Qingdao are used to determine the influence of dust event.

\section{Sampling locations and period}

The Andersen-type low volume air sampler (AN-200, Shibata Co. Ltd.) was used at three Chinese stations shown in Fig. 1. The air sampler was fixed on the roof of a building to prevent as much as possible from collecting local surface material carried by the wind. The AN-200 obtains the grain size distribution data of aeolian dust: the particle size classification is $>11 \mu \mathrm{m}$, 11-7.0 $\mu \mathrm{m}, 7.0-4.7 \mu \mathrm{m}, 4.7-3.3 \mu \mathrm{m}, 3.3-2.1 \mu \mathrm{m}, 2.1$ $1.1 \mu \mathrm{m}, 1.1-0.65 \mu \mathrm{m}, 0.65-0.43 \mu \mathrm{m}$, and $<0.43 \mu \mathrm{m}$. The quartz filter (Tokyo Dylec, 2500QAT-UP) was used to collect fine particles $(0.65-0.43 \mu \mathrm{m}$ and $<0.43 \mu \mathrm{m})$, and other particles were trapped by the PF-050 polyflon filter (Advantec Co. Ltd.). The AN-200 was operated for 7-20 days during the usual observation period and 1-8 days during the first intensive observation period (IOP) (IOP 1: 8-21 April 2002). According to Zhang et al. (2002) and Kanai et al. (2003), large-scale dust events were observed on March 19-22 and April 8-12, 2002 in China. Eight aeolian dust samples (four for Beijing and two for Hefei and Qingdao) were analyzed here. The three samples of Beijing no. 002 and no. 003 and Qingdao no. 022 were collected during a dust event. No sample was collected at Hefei in a dust event.

\section{Analytical Methods}

The water-soluble and water-insoluble components in dust samples were analyzed based on the reports of 
Kanai et al. (2002) and Ohta et al. (2003). The soluble component of a quarter of the filter obtained by AN200 was leached with a mixture of ethanol and Milli Q water (MQ). The insoluble fractions were separated by a cellulose acetate-type membrane filter. The composition of the eluent determined by an ion chromatograph will be discussed in another paper.

The insoluble fraction trapped on a quarter of the polyflon filter and membrane filter was decomposed with $\mathrm{HNO}_{3}, \mathrm{HClO}_{4}$, and HF. Fifty-one elements were determined by a Thermo Jarrell Ash IRIS ICP-AES $\left(\mathrm{Na}_{2} \mathrm{O}, \mathrm{MgO}, \mathrm{Al}_{2} \mathrm{O}_{3}, \mathrm{P}_{2} \mathrm{O}_{5}, \mathrm{~K}_{2} \mathrm{O}, \mathrm{CaO}, \mathrm{TiO}_{2}, \mathrm{MnO}\right.$, Total $\mathrm{Fe}_{2} \mathrm{O}_{3}\left(\mathrm{~T}-\mathrm{Fe}_{2} \mathrm{O}_{3}\right), \mathrm{V}, \mathrm{Sr}$, and $\left.\mathrm{Ba}\right)$ and an Agilent Technologies HP4500 ICP-MS (Li, Be, Sc, Cr, Co, Ni, Cu, $\mathrm{Zn}, \mathrm{Ga}, \mathrm{Rb}, \mathrm{Zr}, \mathrm{Nb}, \mathrm{Mo}, \mathrm{Cd}, \mathrm{Sn}, \mathrm{Sb}, \mathrm{Cs}, \mathrm{REE}$ ( $\mathrm{Y}$ and lanthanide), $\mathrm{Hf}, \mathrm{Ta}, \mathrm{Tl}, \mathrm{Pb}, \mathrm{Bi}$, Th, and $\mathrm{U})$. The analytical results are shown in the Appendix. The analytical values in two fine fractions $(0.65-0.45 \mu \mathrm{m}$ and $<0.45 \mu \mathrm{m})$ were semiquantitative because of the high blank values in the quartz filter (Ohta et al., 2003, 2005b).

\section{Results and Discussion}

\subsection{Aerosol concentrations at Beijing, Hefei, and Qingdao in spring 2002}

Figure 2 shows the mass concentrations of aeolian dust samples at three Chinese stations in spring 2002, and the data are quoted from Kanai et al. (2003). When dust events were observed, total dust concentrations were extremely high at the Beijing and Qingdao stations, and the mass concentrations in coarse grains of over $2.1 \mu \mathrm{m}$ markedly increased (see BJ002, BJ003, and QD022 in Fig. 2).

The mass concentrations of four dust samples collected at Beijing were all high in coarse grains, but their distribution patterns were not very similar to one another. When dust events were observed, the mass concentrations of BJ002 increased in coarse grains (over $2.1 \mu \mathrm{m}$ ), but those of BJ003 increased throughout all particle sizes. At the Qingdao and Hefei stations, the mass concentrations of aeolian dust were characterized by a broad peak from $7 \mu \mathrm{m}$ to $2 \mu \mathrm{m}$. In the dust event, the concentrations of dust samples (QD022) with 7.0-2.1 $\mu \mathrm{m}$ particle size remarkably increased. Except for QD022, the mass concentrations of aeolian dust collected at Qingdao and Hefei had similar patterns against particle size to one another. The mass concentration of BJ002 in coarse grains (over $7 \mu \mathrm{m}$ ) was much higher than those of QD022, although they were collected in the dust event of March. Their difference will indicate that the coarse grains effectively fell out during transportation.

\subsection{Analytical result of a water-insoluble component}

The insoluble fraction of a coarse-medium grain of
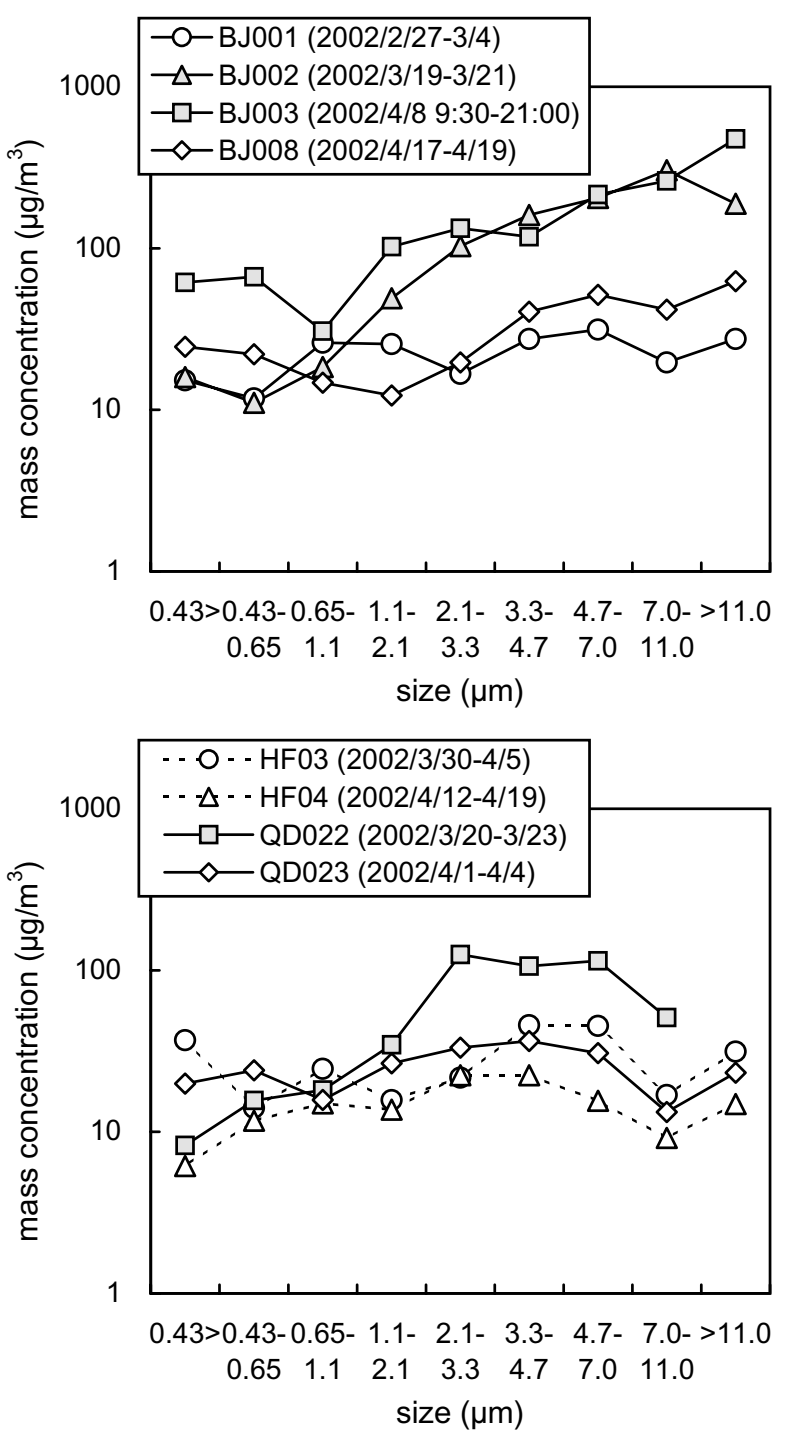

Fig. 2 Distribution of aerosol concentrations among particle size at the Beijing, Hefei, and Qingdao stations. The data are quoted from Kanai et al. (2003). The solid symbols indicate that the sample was collected in a dust event.

aeolian dust $(>2-1 \mu \mathrm{m})$ consists mainly of mineral aerosol and that of a fine fraction $(<2-1 \mu \mathrm{m})$ is composed mainly of carbon aerosol, which is released by a vehicle, plant and heating system and contains large amounts of anthropogenic materials. Next to Si, aluminum is the second most abundant element in minerals such as feldspar and clay minerals (illite and chlorite), and its concentration is used as a good indicator of the contribution of mineral aerosol (Inst. Hydrospheric Sci. Nagoya Univ., 1991; Yabuki et al., 2002).

Figure 3 shows the $\mathrm{Al}_{2} \mathrm{O}_{3}$ concentration of an insoluble fraction. The $\mathrm{Al}_{2} \mathrm{O}_{3}$ concentrations for Beijing samples were constant from $>11 \mu \mathrm{m}$ to 2.1 (or 3.3) $\mu \mathrm{m}$, but they steeply decreased below 2.1 (or 3.3) $\mu \mathrm{m}$. At the Qingdao and Hefei stations, the $\mathrm{Al}_{2} \mathrm{O}_{3}$ concen- 

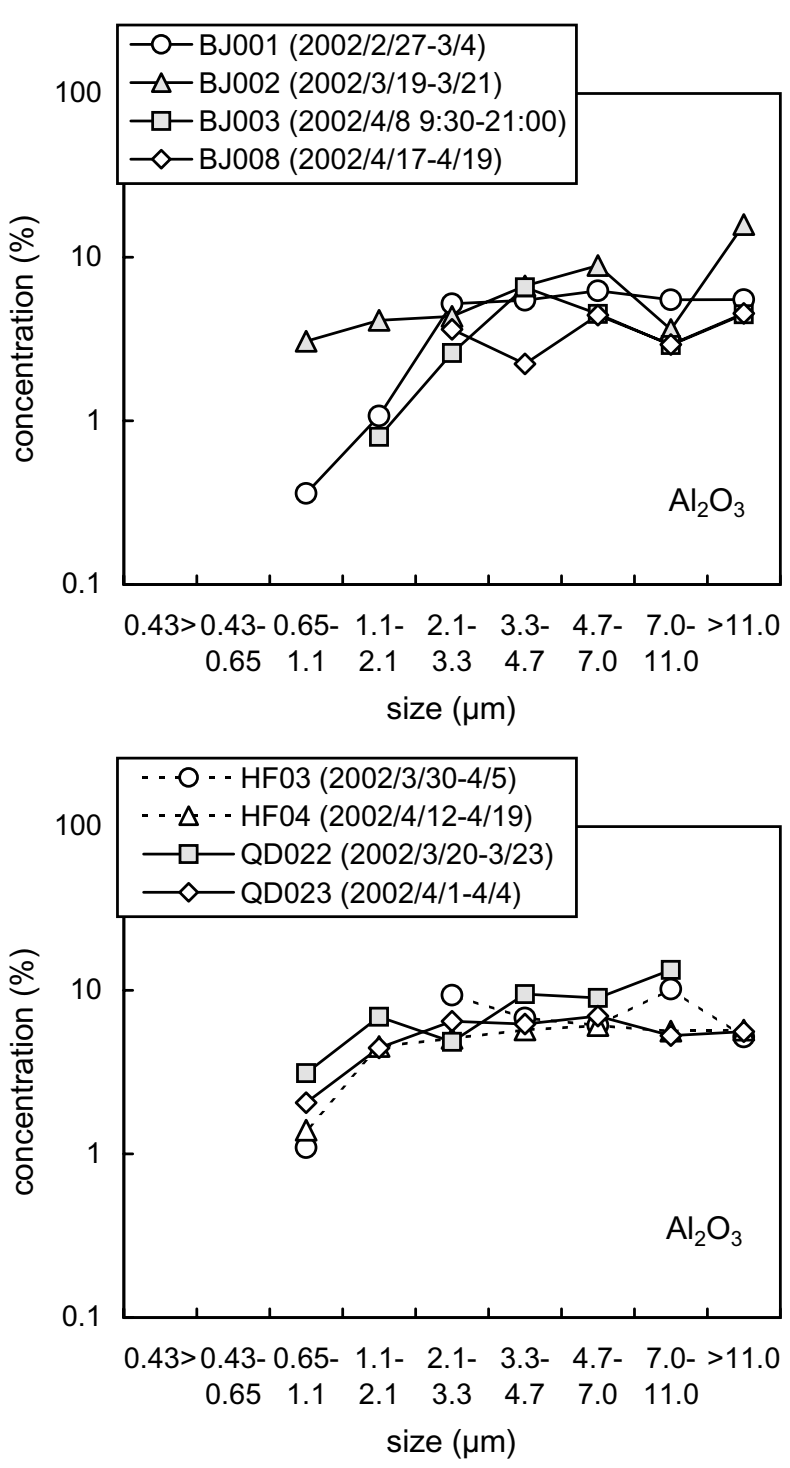

Fig. 3 The distribution of $\mathrm{Al}_{2} \mathrm{O}_{3}$ concentration in dust samples against particle size at three Chinese stations. The symbols are the same as those in Fig. 2.

trations for aeolian dust samples were constant from $>11 \mu \mathrm{m}$ to $1.1 \mu \mathrm{m}$ and suddenly decreased below 1.1 $\mu \mathrm{m}$. These results suggest that the contribution of mineral aerosol sharply decreased below 1.1-3.3 $\mu \mathrm{m}$. Nevertheless, the BJ002, which was collected on March 19-22 in a large-scale dust event, is only sample without a sudden decrease of $\mathrm{Al}_{2} \mathrm{O}_{3}$ concentration. This fact indicates that the dust event of March provided a large amount of mineral aerosol even in the fine grains at Beijing. Although the QD022 was collected in the same dust event in March, it had a steep fall of $\mathrm{Al}_{2} \mathrm{O}_{3}$ concentration in the fine grains. It is assumed that the aeolian dust fell out during its transportation from Beijing to Qingdao so it made a small contribution to the local materials accumulated around Qingdao station. The BJ003 collected in another dust event of April had comparable mass concentrations of aeolian dust to $\mathrm{BJ} 002$. However, the $\mathrm{Al}_{2} \mathrm{O}_{3}$ concentration of $\mathrm{BJ} 003$ was almost the same as those of BJ001 and BJ008. The high mass concentrations of medium-fine grains (below 2.1-3.3 $\mu \mathrm{m}$ ) for BJ003 were probably caused not only by mineral aerosol conveyed from inland China in the dust event but also by local minerals, carbon aerosol, and soluble fractions $\left(\left(\mathrm{NH}_{4}\right)_{2} \mathrm{SO}_{4}, \mathrm{NaNO}_{3}\right.$, $\mathrm{CaCO}_{3}$ and other fractions).

Figure 4 shows the variation of chemical compositions with grain size for eight elements $\left(\mathrm{Na}_{2} \mathrm{O}, \mathrm{P}_{2} \mathrm{O}_{5}\right.$, $\mathrm{T}-\mathrm{Fe}_{2} \mathrm{O}_{3}, \mathrm{Cu}, \mathrm{Rb}, \mathrm{Zr}$, La, and $\mathrm{Pb}$ ). The $\mathrm{Na}_{2} \mathrm{O}, \mathrm{P}_{2} \mathrm{O}_{5}$, T$\mathrm{Fe}_{2} \mathrm{O}_{3}, \mathrm{Rb}, \mathrm{Zr}$, and La have almost the same distribution patterns as $\mathrm{Al}_{2} \mathrm{O}_{3}$. Accordingly, they are also originated from mineral aerosol. Some elements, $\mathrm{Cr}, \mathrm{Ni}$, $\mathrm{Cu}, \mathrm{Zn}, \mathrm{Mo}, \mathrm{Cd}, \mathrm{Sn}, \mathrm{Sb}, \mathrm{Pb}$, and $\mathrm{Bi}$, have partly or totally different distribution patterns from $\mathrm{Al}_{2} \mathrm{O}_{3}$. At the Beijing station, there was a dramatic rise of $\mathrm{Cu}$ and $\mathrm{Pb}$ concentrations below $3.3 \mu \mathrm{m}$ in a normal period (BJ001 and BJ008) and below $2.1 \mu \mathrm{m}$ in a dust event (BJ002 and BJ003). At Qingdao and Hefei stations, there were also sudden increases of $\mathrm{Cu}$ and $\mathrm{Pb}$ concentrations below $2.1 \mu \mathrm{m}$ or $3.3 \mu \mathrm{m}$. The high concentrations for $\mathrm{Cu}$ and $\mathrm{Pb}$ in the finer grains suggest that these elements originated mainly from anthropogenic materials. However, the $\mathrm{Cu}$ and $\mathrm{Pb}$ concentrations below $2.1 \mu \mathrm{m}$ in a dust event were relatively lower than those absent from a dust event both at the Beijing and Qingdao stations with some exceptions. This fact indicates that a large amount of mineral aerosol, whose $\mathrm{Cd}, \mathrm{Sn}, \mathrm{Sb}, \mathrm{Pb}$ and $\mathrm{Bi}$ concentrations are low, diminished the influence of anthropogenic materials on large particles when a large-scale dust event was observed.

\subsection{Elemental concentrations normalized by $\mathrm{Al}_{2} \mathrm{O}_{3}$ content}

As mentioned above, the $\mathrm{Al}_{2} \mathrm{O}_{3}$ concentration is used as an indicator of the contribution of mineral aerosol. Therefore, dividing the elemental concentrations by the $\mathrm{Al}_{2} \mathrm{O}_{3}$ contents is useful for examining the change of mineralogical composition or estimating the influence of non-silicate minerals and anthropogenic materials (Inst. Hydrosphere Sci. Nagoya Univ., 1991). Figure 5 shows the chemical compositions normalized by the $\mathrm{Al}_{2} \mathrm{O}_{3}$ content. The $\mathrm{P}_{2} \mathrm{O}_{5}, \mathrm{~T}-\mathrm{Fe}_{2} \mathrm{O}_{3}, \mathrm{Rb}, \mathrm{Zr}$, and $\mathrm{La}$ had a flat or slightly increasing trend with the decrease of particle size, but the fine particles below 1-2 $\mu \mathrm{m}$ had a sudden increase of these ratios. The element concentration ratio showed no systematic differences among sampling location and between the dust events and non-dust event. Therefore, it is concluded that the mineral composition is constant from $>11 \mu \mathrm{m}$ to $1-2$ $\mu \mathrm{m}$, but changes under $1-2 \mu \mathrm{m}$; the mineralogical composition of aeolian dust coming from inland China is not much different from those of local materials.

The concentration ratios of $\mathrm{Na}_{2} \mathrm{O}$ and $\mathrm{CaO}$ to $\mathrm{Al}_{2} \mathrm{O}_{3}$ 

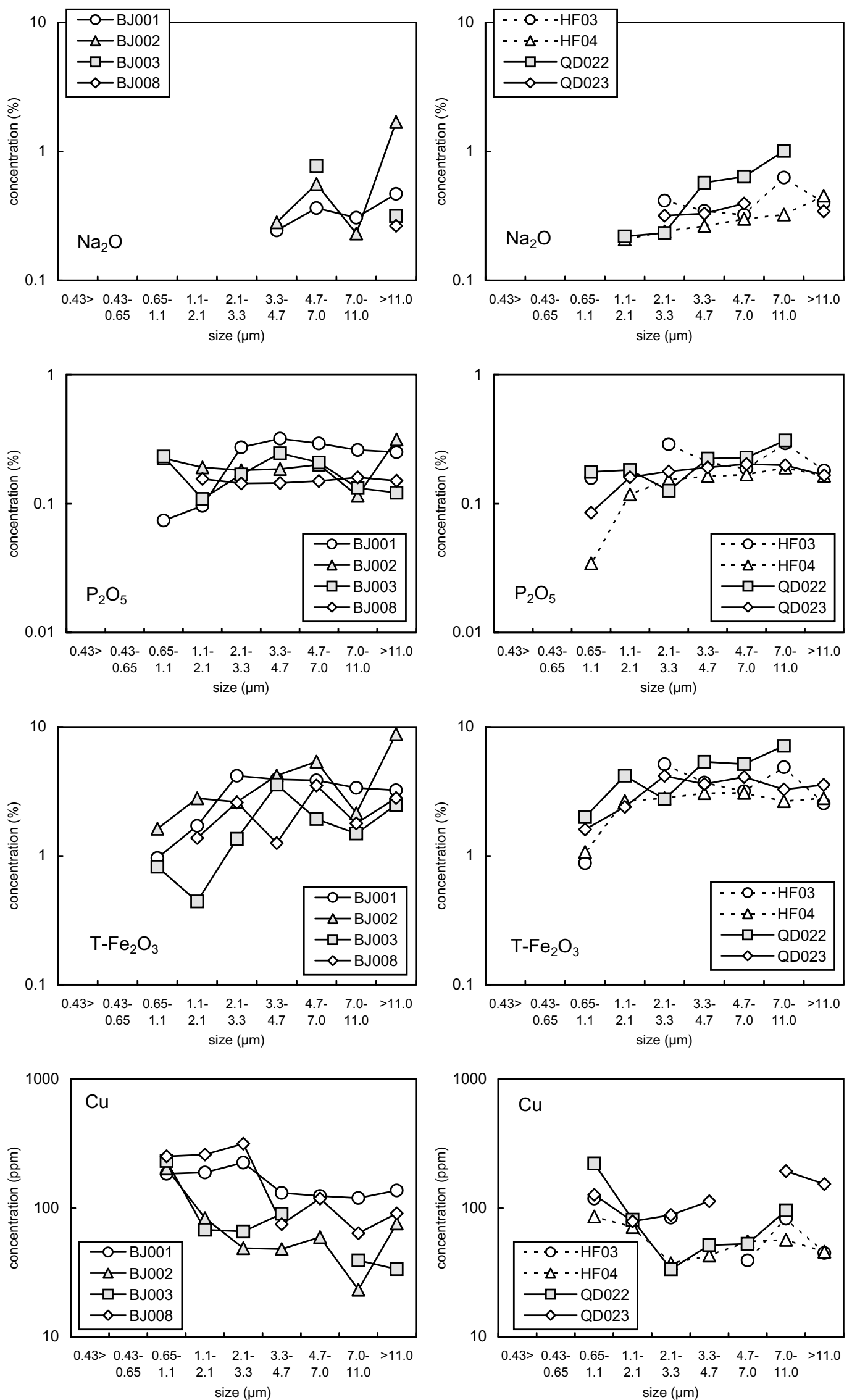

Fig. 4 The distribution of $\mathrm{Na}_{2} \mathrm{O}, \mathrm{P}_{2} \mathrm{O}_{5}, \mathrm{~T}-\mathrm{Fe}_{2} \mathrm{O}_{3}, \mathrm{Cu}, \mathrm{Rb}, \mathrm{Zr}$, La and $\mathrm{Pb}$ concentrations in dust samples against particle size at three Chinese stations. The symbols are the same as those in Fig. 2. 

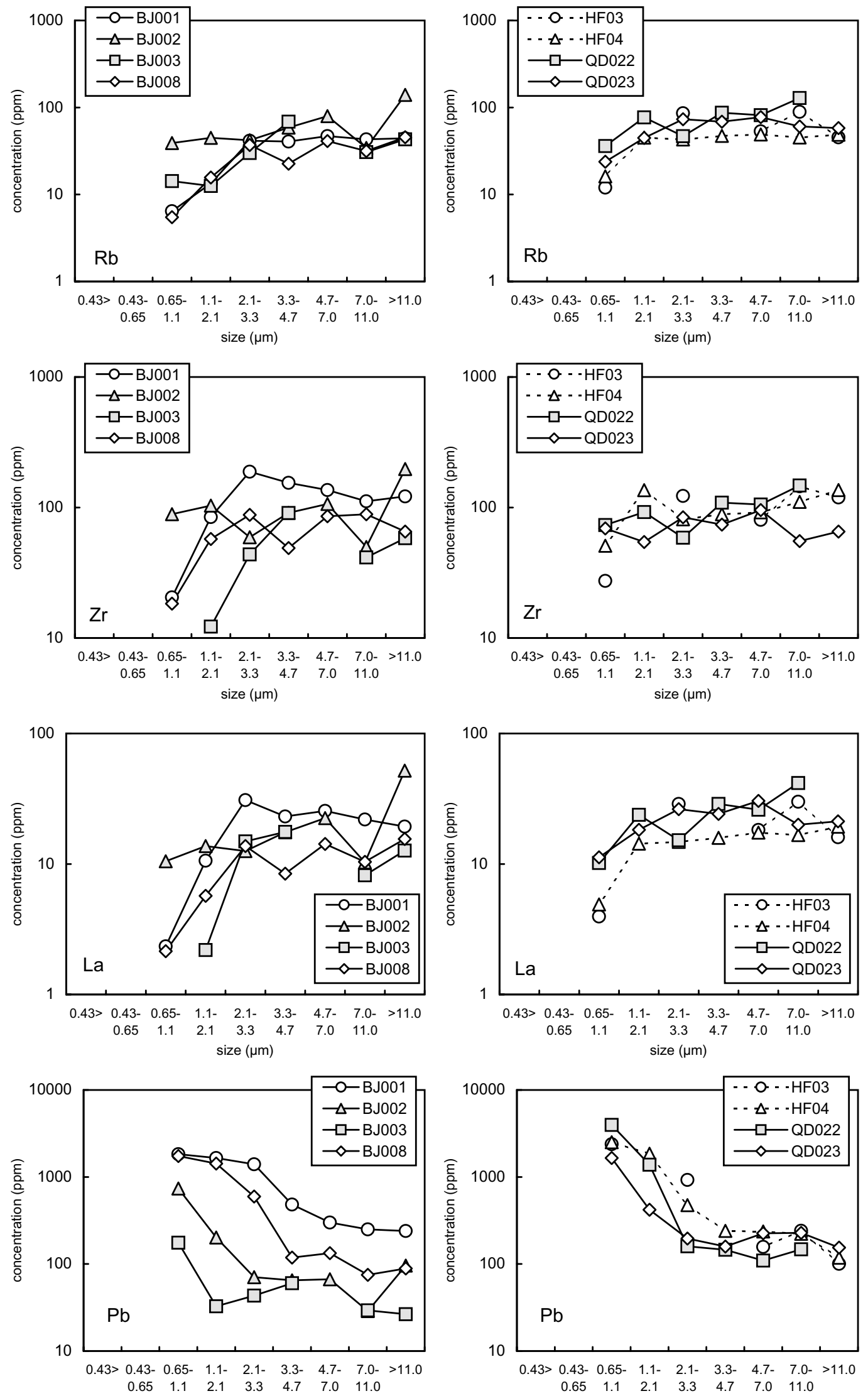

Fig. 4 (continue) 

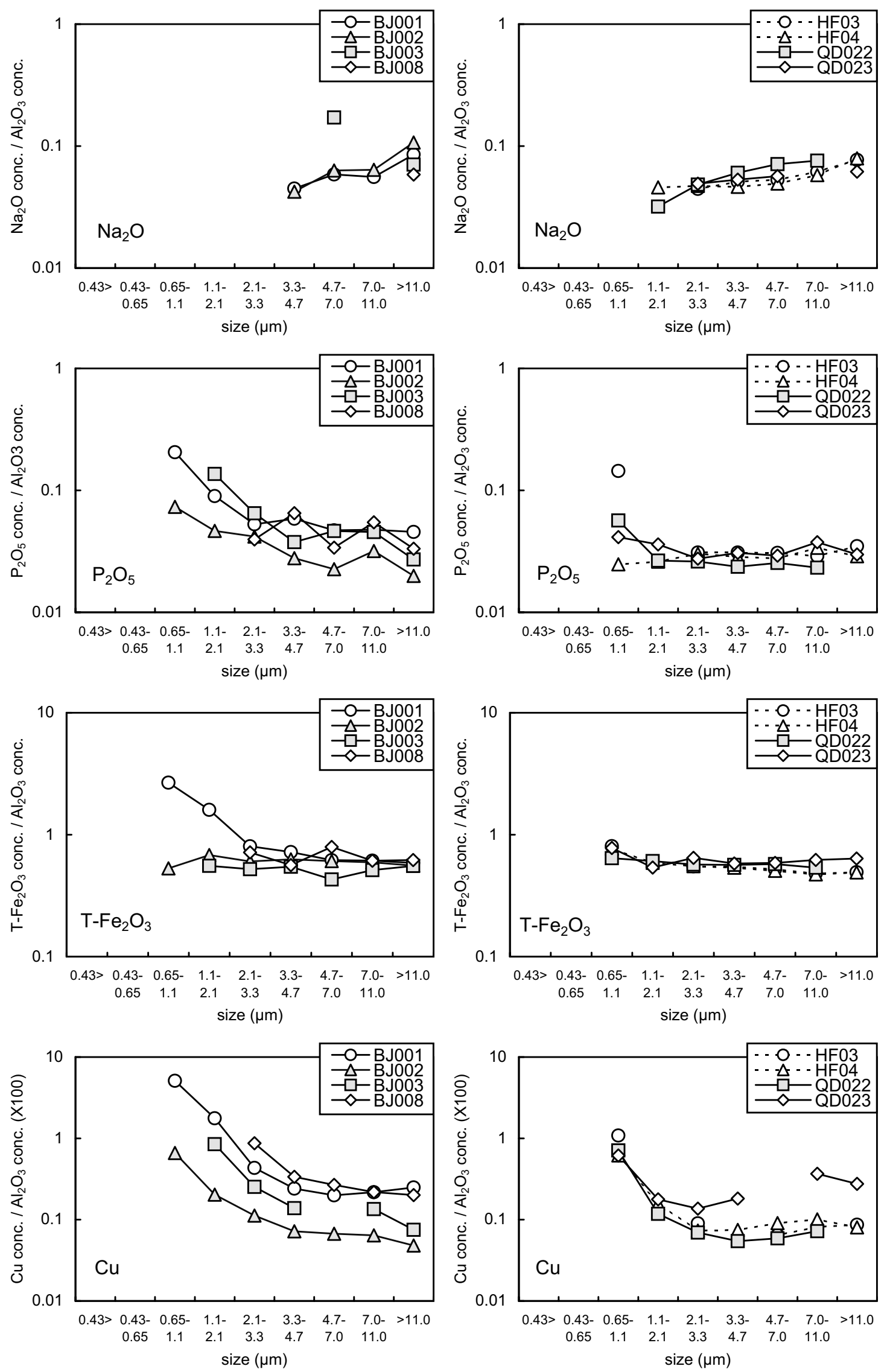

Fig. 5 The concentration ratios of major and some minor elements to $\mathrm{Al}_{2} \mathrm{O}_{3}$. The symbols are the same as those in Fig. 2. 

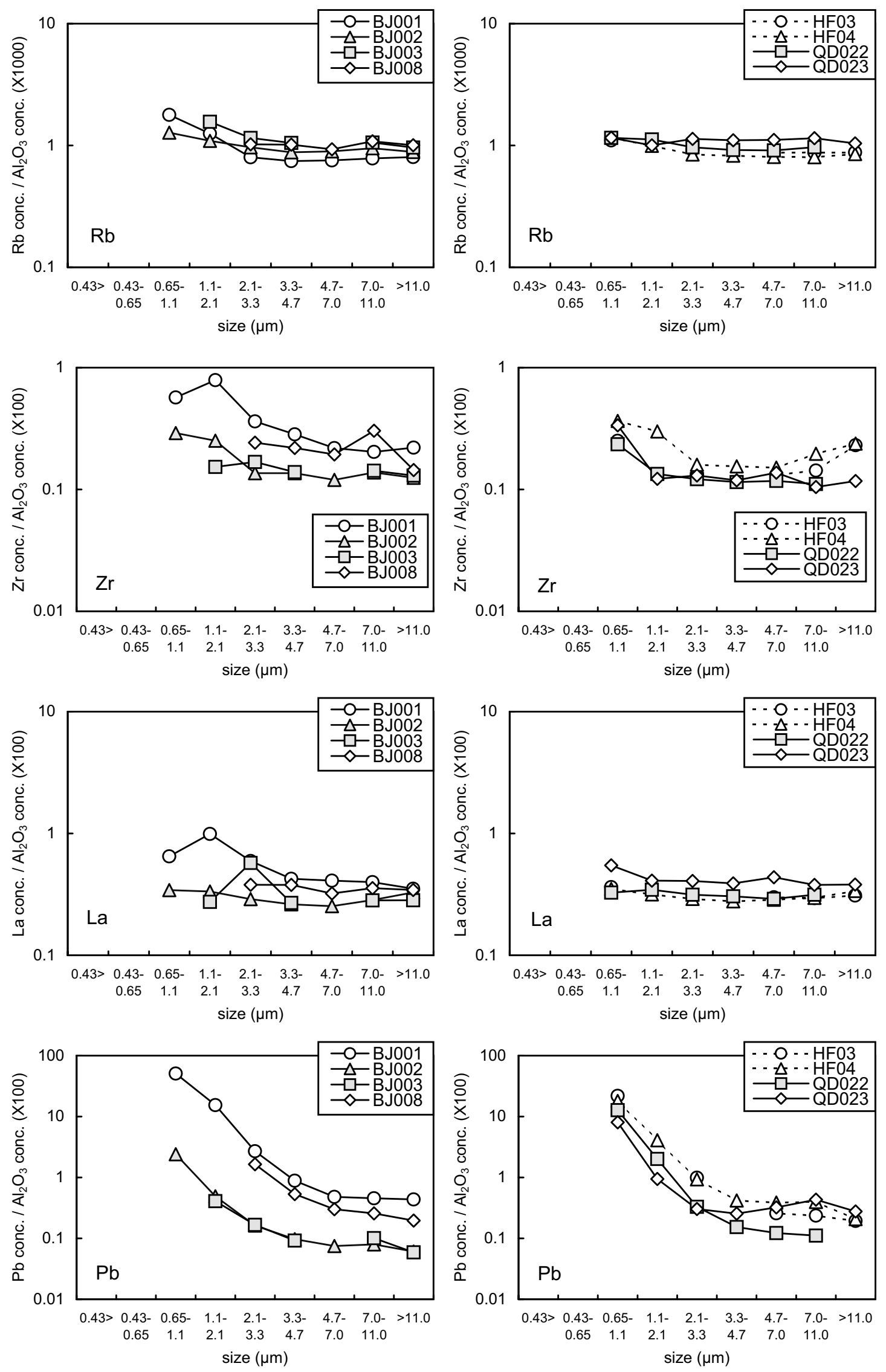

Fig. 5 (continue) 
for all samples moderately decreased with the decrease of particle size (see $\mathrm{Na}_{2} \mathrm{O}$ in Fig. 5). The decreasing trend suggests that the mineralogical composition may gradually change. Ohta et al. (2003) presumed that $\mathrm{Na}^{+}, \mathrm{K}^{+}$and $\mathrm{Ca}^{2+}$ trapped in a clay mineral and nonsilicate mineral (e.g. calcite, gypsum and sea salts) agglutinating with coarser grains were not dissolved enough in MQ.

The concentration ratios of $\mathrm{Cr}, \mathrm{Ni}, \mathrm{Cu}, \mathrm{Zn}, \mathrm{Mo}, \mathrm{Cd}$, $\mathrm{Sn}, \mathrm{Sb}, \mathrm{Pb}$, and $\mathrm{Bi}$ to $\mathrm{Al}_{2} \mathrm{O}_{3}$ for dust samples with particle size over 3.3-2.1 $\mu \mathrm{m}$ were constant, but increased with the decrease of the particle size below 3.3-2.1 $\mu \mathrm{m}$ (see $\mathrm{Cu}$ and $\mathrm{Pb}$ in Fig. 5). The gentle increasing trend is an inherent nature of aeolian dust because a similar trend has also been found in the concentration ratios for other elements except for $\mathrm{Na}_{2} \mathrm{O}$ and $\mathrm{CaO}$. The concentration ratios of fine grains for most elements increased several fold than those of coarse grains, and those for heavy metals increased tenfold to hundredfold with decreasing particle size. Therefore, the increasing trend for these elements indicates that the fraction of anthropogenic materials increased with decreasing particle size.

Interestingly, the elemental concentration ratios in Fig. 5 had basically the same trend against particle size irrespective of sampling stations or the occurrence of a dust storm. This result indicates that chemical features of aeolian dust are similar. In other words, it is difficult to specify the origin of aeolian dust by using its chemical composition. However, some elements had systematic differences. The $\mathrm{Cu}, \mathrm{Zr}, \mathrm{La}$, and $\mathrm{Pb}$ to $\mathrm{Al}_{2} \mathrm{O}_{3}$ concentration ratios for samples collected at the Beijing station were smaller when a dust event was observed, although there were little systematic changes in the distribution pattern. The concentration ratios of Qingdao and Hefei had similar values to those of Beijing in a dust event, but were lower than those of Beijing in a normal period. However, there was no systematic change of concentration ratios at the Qingdao station between a dust event and non-dust event. Accordingly, local materials in Beijing have a relatively high concentration for these elements.

\section{Conclusion}

The authors have examined the chemical differences of aeolian dust among sampling locations (Beijing, Qingdao, and Hefei) and influence of aeolian dust coming from inland China on local suspended materials. The chemical compositions of aeolian dust conveyed from inland China are not much different from those of local materials, except for some heavy metals such as $\mathrm{Cu}$ and $\mathrm{Pb}$, which are released by an anthropogenic activity. The elements $/ \mathrm{Al}_{2} \mathrm{O}_{3}$ values, which exhibit a change of mineralogical composition or contribution of non-silicate minerals and anthropogenic materials, did not systematically change among sampling locations or between a dust event and non-dust event. In conclusion, the chemical properties of aeolian dust are very constant.

Acknowledgements: This study was partly supported by the Special Coordination Fund of the Ministry of Education, Culture, Sports, Science and Technology of Japan.

\section{References}

Institute of Hydrospheric Sciences, Nagoya University (1991) Atmospheric-hydrospheric Science - Kosa-. Kokinshoin, 328p (in Japanese).

Kanai, Y., Ohta, A., Kamioka, H., Terashima, Matsuhisa, Y., Shimizu, H., Takahashi, Y., Kai, K., Xu, B., Hayashi, M. and Zhang, R. (2002) Preliminary study on the grainsize distribution and concentration of aeolian dust collected in Japan. J. Arid Land Studies, 11, 307-314.

Kanai, Y., Ohta, A., Kamioka, H., Terashima, S., Imai, N., Matsuhisa, Y., Kanai, M., Shimizu, H., Takahashi, Y., Kai, K., Xu, B., Hayashi, M. and Zhang, R. (2003) Variation of concentrations and physicochemical properties of aeolian dust obtained in east China and Japan from 2001 to 2002. Bull. Geol. Surv. Japan, 54, 251-267.

National Institute for Environmental Studies (2001) International cooperation research on the methodological development for urban aerosol characteristics in China. Report of Special Research from the National Institute for Environmental Studies, Japan., SR-432001, 59p (in Japanese).

Ohta, A., Terashima, S., Kanai, Y., Kamioka, H., Imai, N., Matsuhisa, Y., Shimizu, H., Takahashi, Y., Kai, K., Hayashi, M. and Zhang, R. (2003) Grain-size distribution and chemical composition of water-insoluble components in aeolian dust collected in Japan in spring 2002. Bull. Geol. Surv. Japan, 54, 303-322.

Ohta, A., Tsuno, H., Kagi, H., Kanai, Y. and Nomura, M. (2004) XAFS analysis of Fe, Mn, and Zn of an aeolian dust during transportation from China to Japan. KEK Report, 21B, 20.

Ohta, A., Kanai, Y., Terashima, S., Kamioka, H., Imai, N., Matsuhisa, Y., Shimizu, H., Takahashi, Y., Kai, K., Hayashi, M., Zhang, R., Tsuno, H., Kagi, H. and Nomura, M. (2005a) Elucidation of elemental behavior of aeolian dust transported from China to Japan. Proceedings of the 4th ADEC (Aeolian Dust Experiment on Climate Impact) Workshop, 297-300.

Ohta, A., Terashima, S., Kanai, Y., Kamioka, H., Imai, N., Matsuhisa, Y., Shimizu, H., Takahashi, Y., Kai, K., Hayashi, M. and Zhang, R. (2005b) Seasonal change of chemical composition of water-insoluble components in aerosol particles collected in Tsukuba from February 2001 to June 2002. Bull. Geol. Surv. Japan, 
56, 99-116 (in Japanese with English abstract.).

Yabuki, S., Kanayama, S., Fu, F., Honda, M., Yanagisawa, F., Wei, W., Zheng, F., Liu, M., Shen, Z. and Liu, L. (2002) Physical and chemical characteristics of aeolian dust collected over Asian dust source regions in China-Comparison with atmospheric aerosols in an urban area at Wako, Japan. J. Arid Land Studies, 11, 273-289.

Zhang, R., Shi, G., Kanai, Y., Ohta, A., Xu, Y., Gong, Y. and Chen, H. (2002) TSP mass concentration and number concentration of particles in dust storm weather in 2002 spring of Beijing. The Chinese Journal of Process Engineering, 2, 289-292. (in Chinese with English abstract).

Zhang, R., Wang, M., Zhang, X. and Zhu, G. (2003a) Analysis on the chemical and physical properties of particles in a dust storm in spring in Beijing. Powder Technology, 137, 77-82.

Zhang, R., Xu, Y. and Han, Z. (2003b) Inorganic chemical composition and source signature of $\mathrm{PM}_{2.5}$ in Beijing during ACE-Asia period. Chinese Science Bulletin, 48, 1002-1005.

Received March 29, 2005

Accepted July 21, 2005

\section{中国で 2002 年春に採取した風送ダストの非水溶性成分の化学的特徴

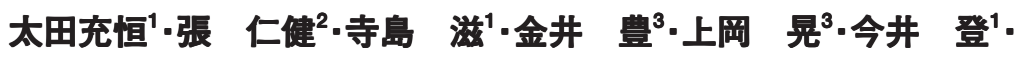 松久幸敬 ${ }^{1}$.清水 洋 $^{4}$.高橋諪夫 ${ }^{4}$.甲斐憲次 ${ }^{5}$-林 政彦 ${ }^{6}$ \\ 要 旨}

2002 年春に中国の北京, 青島, 合肥の 3 地点で風送ダスト試料を採取し, 化学分析を行い, その特徴について検 討を行った。大気中ダストは粗い粒径側で濃度が高く, 粒径に対する濃度変化は試料採取地点によって異なってい た。 ダストイベントが発生した時は, $2 \mu \mathrm{m}$ 以上の粒子に著しい増加が認められた。一例外を除く全ての試料の化学 組成 $\left(\mathrm{Al}_{2} \mathrm{O}_{3} \mathrm{Na}_{2} \mathrm{O}, \mathrm{P}_{2} \mathrm{O}_{5}\right.$, Total $\mathrm{Fe}_{2} \mathrm{O}_{3}, \mathrm{Rb}, \mathrm{Zr}$, and La) は, 粗大粒子側ではほぼ濃度が一定であるが $1.1 〜 2.1 \mu \mathrm{m}$ りも細かい粒子に揸いて急激に減少した。この結果は, 鉱物質エアロゾルの寄与が細粒粒子で著しく減少すること を表している。ただし, 3 月に北京で観測されたダストイベントでは, これらの元素は粒径変化に関係なくほぼ一定 の濃度を示した。この結果は, 大規模なダストイベントは細粒粒子に拈いても大量の鉱物質エアロゾルを供給して いることを表している。元素濃度と $\mathrm{Al}_{2} \mathrm{O}_{3}$ 濃度の比を見たところ, 粗粒 - 中粒にかけてほぼ一定の值を示すものの 1 〜 $2 \mu \mathrm{m}$ を境に急激に減少する。すなわち, 鉱物組成は粗粒 - 中粒ダストではほぼ均質であるが細粒粒子側で変化 することを示している，元素濃度比の粒径に対する変化に着目すると，ダストイベントの有無や 3 試料採取地点間 に系統的な違いは認められなかった。したがって, 中国内陸部から運ばれる風送ダストと試料採取地点周辺から巻 き上げられた物質の化学組成には共通点が多いことを示している。一方,いくつかの重金属元素 $(\mathrm{Cr}, \mathrm{Ni}, \mathrm{Cu}, \mathrm{Zn}, \mathrm{Mo}$, $\mathrm{Cd}, \mathrm{Sb}, \mathrm{Sn}, \mathrm{Pb}$, and $\mathrm{Bi})$ は, 鉱物質エアロゾル起源の元素 $\left(\mathrm{Al}_{2} \mathrm{O}_{3}\right.$ など) とは異なる特徵を示した。 これらの元素の 濃度及び $\mathrm{Al}_{2} \mathrm{O}_{3}$ 濃度比は粒径が細かくなるに従って著しく増加する。例えば, $\mathrm{Cu} / \mathrm{Al}_{2} \mathrm{O}_{3}$ 比と $\mathrm{Pb}_{2} / \mathrm{Al}_{2} \mathrm{O}_{3}$ 比は粒径が細 かくなるに従って，10〜 100 倍も劇的な増加を示した。これらの粒径に対する変化は細かい粒子ほど人為起源物質 の寄与が多いことを示している. 
Appendix. Analytical results of aeolian dust collected in Beijing, Hefei and Qingdao from February to spring in 2002.

\begin{tabular}{|c|c|c|c|c|c|c|c|c|c|c|c|c|c|c|}
\hline Stage & $\begin{array}{c}\text { size (um) } \\
(\mu \mathrm{m}) \\
\end{array}$ & $\begin{array}{c}\text { weight } \\
(\mathrm{mg})\end{array}$ & $\begin{array}{c}\mathrm{Na}_{2} \mathrm{O} \\
(\%) \\
\end{array}$ & $\begin{array}{r}\mathrm{MgO} \\
(\%) \\
\end{array}$ & $\begin{array}{c}\mathrm{Al}_{2} \mathrm{O}_{3} \\
(\%) \\
\end{array}$ & $\begin{array}{l}\mathrm{P}_{2} \mathrm{O}_{5} \\
(\%) \\
\end{array}$ & $\begin{array}{l}\mathrm{K}_{2} \mathrm{O} \\
(\%) \\
\end{array}$ & $\begin{array}{l}\mathrm{CaO} \\
(\%) \\
\end{array}$ & $\begin{array}{l}\mathrm{TiO}_{2} \\
(\%) \\
\end{array}$ & $\begin{array}{r}\mathrm{MnO} \\
(\%) \\
\end{array}$ & $\begin{array}{c}\mathrm{T}-\mathrm{Fe}_{2} \mathrm{O}_{3} \\
(\%) \\
\end{array}$ & $\begin{array}{c}\mathrm{Li} \\
\mathrm{ppm} \\
\end{array}$ & $\begin{array}{c}\mathrm{Be} \\
\mathrm{ppm}\end{array}$ & $\begin{array}{r}\mathrm{Sc} \\
\mathrm{ppm}\end{array}$ \\
\hline \multicolumn{15}{|c|}{ Beijing no.001: $2002 / 2 / 27-3 / 4$, total flow $=204 \mathrm{~m}^{3}$} \\
\hline 0 & $>11.0$ & 5.6 & 0.5 & 1.4 & 5.5 & 0.3 & 0.9 & 2.46 & 0.3 & 0.04 & 3.2 & 32 & 3 & 9 \\
\hline 1 & $7.0-11.0$ & 4.0 & 0.3 & 1.5 & 5.5 & 0.3 & 0.8 & 1.88 & 0.2 & 0.05 & 3.4 & 34 & 4 & 8 \\
\hline 2 & $4.7-7.0$ & 6.4 & 0.4 & 1.5 & 6.2 & 0.3 & 0.9 & 2.60 & 0.3 & 0.05 & 3.9 & 42 & 5 & 10 \\
\hline 3 & 3.3-4.7 & 5.6 & 0.2 & 1.1 & 5.5 & 0.3 & 0.8 & 1.61 & 0.3 & 0.04 & 3.9 & 36 & 5 & 8 \\
\hline 4 & $2.1-3.3$ & 3.4 & & 0.8 & 5.2 & 0.3 & 0.6 & & 0.3 & 0.04 & 4.2 & 37 & 5 & 10 \\
\hline 5 & $1.1-2.1$ & 5.2 & & & 1.1 & 0.1 & & & 0.07 & 0.03 & 1.7 & 11 & 2 & 4 \\
\hline 6 & $0.65-1.1$ & 5.3 & & & 0.4 & 0.07 & & & 0.02 & 0.03 & 1.0 & 5 & 1 & 0.6 \\
\hline 7 & $0.43-0.65$ & 2.4 & & & & & & & & 0.03 & & & & \\
\hline $\mathrm{BU}$ & $0.43>$ & 3.1 & & & & & & & & 0.02 & & & & \\
\hline Beijing no & $2: 2002 / 3 / 1$ & $-3 / 21$, to & flow $=8$ & $.5 \mathrm{~m}^{3}$ & & & & & & & & & & \\
\hline 0 & $>11.0$ & 15.4 & 1.7 & 3.1 & 15.8 & 0.3 & 3.1 & 4.26 & 1.0 & 0.14 & 8.8 & 67 & 4 & 21 \\
\hline 1 & $7.0-11.0$ & 24.8 & 0.2 & 0.8 & 3.6 & 0.1 & 0.7 & 0.85 & 0.2 & 0.03 & 2.1 & 16 & 1 & 5 \\
\hline 2 & $4.7-7.0$ & 16.7 & 0.6 & 1.6 & 8.9 & 0.2 & 1.7 & 1.80 & 0.5 & 0.09 & 5.4 & 44 & 3 & 12 \\
\hline 3 & 3.3-4.7 & 13.1 & 0.3 & 1.3 & 6.7 & 0.2 & 1.3 & 1.24 & 0.4 & 0.06 & 4.2 & 32 & 2 & 9 \\
\hline 4 & $2.1-3.3$ & 8.4 & & 1.0 & 4.3 & 0.2 & 0.7 & 0.65 & 0.2 & 0.04 & 2.6 & 21 & 1 & 6 \\
\hline 5 & $1.1-2.1$ & 4.0 & & 0.9 & 4.1 & 0.2 & 0.7 & & 0.2 & 0.04 & 2.8 & 23 & 1 & 10 \\
\hline 6 & $0.65-1.1$ & 1.5 & & & 3.1 & 0.2 & & & 0.10 & 0.03 & 1.6 & 18 & 1 & 10 \\
\hline 7 & $0.43-0.65$ & 0.9 & & & & & & & & & & & & \\
\hline $\mathrm{BU}$ & $0.43>$ & 1.3 & & & & & & & & & & & & \\
\hline Beijing no & 3: $2002 / 4 / 8$ & $9: 30-21$ & , total flc & $w=1.9$ & $\mathrm{~m}^{3}$ & & & & & & & & & \\
\hline 0 & $>11.0$ & 9.3 & 0.3 & 0.9 & 4.5 & 0.1 & 0.7 & 0.84 & 0.3 & 0.04 & 2.5 & 19 & 1 & 6 \\
\hline 1 & $7.0-11.0$ & 5.1 & & 0.5 & 2.9 & 0.1 & 0.4 & & 0.14 & 0.02 & 1.5 & 15 & 0.7 & 4 \\
\hline 2 & $4.7-7.0$ & 4.2 & & 1.1 & 4.5 & 0.2 & 0.8 & 1.60 & 0.2 & 0.04 & 1.9 & & & 6 \\
\hline 3 & 3.3-4.7 & 2.3 & & 1.1 & 6.5 & 0.2 & 1.0 & & 0.3 & 0.06 & 3.6 & 32 & 2 & 9 \\
\hline 4 & $2.1-3.3$ & 2.6 & & & 2.6 & 0.2 & 0.4 & & 0.10 & 0.02 & 1.4 & 15 & 0.7 & 4 \\
\hline 5 & $1.1-2.1$ & 2.0 & & & 0.8 & 0.1 & & & & & 0.4 & 6 & 0.3 & 1 \\
\hline 6 & $0.65-1.1$ & 0.6 & & & & 0.2 & & & & & 0.8 & & 0.3 & \\
\hline 7 & $0.43-0.65$ & & & & & 0.1 & & & & & & & & \\
\hline$B U$ & $0.43>$ & & & & & 0.1 & & & & & & & & \\
\hline Beijing no & $8: 2002 / 4 / 1$ & $-4 / 19$, to & flow $=8$ & $.5 \mathrm{~m}^{3}$ & & & & & & & & & & \\
\hline 0 & $>11.0$ & 5.1 & 0.3 & 1.3 & 4.5 & 0.2 & 0.8 & 3.43 & 0.3 & 0.05 & 2.8 & 26 & 2 & 5 \\
\hline 1 & $7.0-11.0$ & 3.4 & & 0.8 & 2.9 & 0.2 & 0.4 & 1.63 & 0.14 & 0.03 & 1.8 & 17 & 1 & 7 \\
\hline 2 & $4.7-7.0$ & 4.2 & & 1.2 & 4.4 & 0.1 & 0.7 & 2.47 & 0.2 & 0.05 & 3.5 & 28 & 2 & 7 \\
\hline 3 & 3.3-4.7 & 3.3 & & 0.5 & 2.2 & 0.1 & 0.3 & 1.05 & 0.11 & 0.02 & 1.3 & 16 & 1 & 3 \\
\hline 4 & $2.1-3.3$ & 1.6 & & & 3.6 & 0.1 & & & 0.12 & 0.04 & 2.6 & 26 & 2 & 6 \\
\hline 5 & $1.1-2.1$ & 1.0 & & & & 0.2 & & & & 0.04 & 1.4 & 9 & 0.5 & 2 \\
\hline 6 & $0.65-1.1$ & 1.2 & & & & & & & & 0.04 & & & 0.2 & \\
\hline 7 & $0.43-0.65$ & & & & & & & & & 0.03 & & & & \\
\hline $\mathrm{BU}$ & $0.43>$ & & & & & & & & & 0.01 & & & & \\
\hline Hefei no. 0 & 2002/3/30- & 15, total f & $N=214 \mathrm{r}$ & & & & & & & & & & & \\
\hline 0 & $>11.0$ & 6.7 & 0.4 & 0.9 & 5.2 & 0.2 & 0.8 & 2.57 & 0.3 & 0.03 & 2.5 & 26 & 1 & 9 \\
\hline 1 & $7.0-11.0$ & 3.6 & 0.6 & 1.9 & 10.2 & 0.3 & 1.6 & 4.10 & 0.5 & 0.07 & 4.9 & 47 & 2 & 11 \\
\hline 2 & $4.7-7.0$ & 9.7 & 0.3 & 1.1 & 6.1 & 0.2 & 1.1 & 2.48 & 0.3 & 0.04 & 3.2 & 28 & 1 & 7 \\
\hline 3 & 3.3-4.7 & 9.8 & 0.3 & 1.3 & 6.8 & 0.2 & 1.3 & 2.31 & 0.4 & 0.05 & 3.7 & & & \\
\hline 4 & $2.1-3.3$ & 4.6 & 0.4 & 1.8 & 9.3 & 0.3 & 1.6 & 1.85 & 0.5 & 0.06 & 5.1 & 39 & 2 & 10 \\
\hline 5 & $1.1-2.1$ & 3.4 & & & & & & & & & & & & \\
\hline 6 & $0.65-1.1$ & 5.3 & & 0.1 & 1.1 & 0.2 & 0.2 & & 0.06 & 0.02 & 0.9 & 5 & 0.3 & 0.7 \\
\hline 7 & $0.43-0.65$ & 3.0 & & & 1.0 & 0.1 & & & 0.04 & 0.02 & 0.6 & & & \\
\hline $\mathrm{BU}$ & $0.43>$ & & & & 0.3 & 0.04 & & & 0.02 & 0.01 & 0.1 & & & \\
\hline Hefei no. 0 & 2002/4/12- & 119, total & $w=264$ & & & & & & & & & & & \\
\hline 0 & $>11.0$ & 3.9 & 0.5 & 0.9 & 5.7 & 0.2 & 0.9 & 2.16 & 0.3 & 0.04 & 2.8 & 24 & 1 & 6 \\
\hline 1 & $7.0-11.0$ & 2.4 & 0.3 & 0.9 & 5.6 & 0.2 & 0.8 & 1.23 & 0.3 & 0.03 & 2.7 & 24 & 1 & 5 \\
\hline 2 & $4.7-7.0$ & 4.1 & 0.3 & 1.0 & 6.1 & 0.2 & 1.0 & 1.46 & 0.3 & 0.04 & 3.1 & 27 & 1 & 6 \\
\hline 3 & 3.3-4.7 & 5.9 & 0.3 & 0.9 & 5.7 & 0.2 & 1.0 & 0.76 & 0.3 & 0.03 & 3.1 & 25 & 1 & 6 \\
\hline 4 & $2.1-3.3$ & 5.9 & 0.2 & 0.8 & 5.1 & 0.2 & 0.8 & 0.46 & 0.3 & 0.03 & 2.8 & 22 & 1 & 6 \\
\hline 5 & $1.1-2.1$ & 3.6 & 0.2 & 0.7 & 4.5 & 0.1 & 0.8 & & 0.2 & 0.03 & 2.7 & 20 & 1 & 5 \\
\hline 6 & $0.65-1.1$ & 4.0 & & 0.2 & 1.4 & 0.03 & 0.2 & & 0.06 & 0.02 & 1.1 & 7 & 0.4 & 2 \\
\hline 7 & $0.43-0.65$ & 3.1 & & & 1.0 & & & & 0.04 & 0.03 & 0.6 & 7 & & \\
\hline BU & $0.43>$ & 1.6 & & & 1.6 & & & & 0.06 & 0.03 & 0.6 & & & \\
\hline Qingdao $n$ & 022: $2002 / 3$ & $20-3 / 23$ & al flow $=$ & $121 \mathrm{~m}^{3}$ & & & & & & & & & & \\
\hline 0 & $>11.0$ & 0.0 & & & & & & & & & & & & \\
\hline 1 & $7.0-11.0$ & 6.2 & 1.0 & 3.7 & 13.3 & 0.3 & 2.7 & 1.91 & 0.7 & 0.10 & 7.1 & 61 & 3 & 16 \\
\hline 2 & $4.7-7.0$ & 13.9 & 0.6 & 2.2 & 9.0 & 0.2 & 1.9 & 1.68 & 0.5 & 0.07 & 5.2 & 43 & 2 & 11 \\
\hline 3 & $3.3-4.7$ & 12.9 & 0.6 & 2.6 & 9.5 & 0.2 & 2.0 & 1.28 & 0.5 & 0.08 & 5.4 & 50 & 2 & 13 \\
\hline 4 & $2.1-3.3$ & 15.2 & 0.2 & 1.5 & 4.8 & 0.1 & 0.9 & 0.49 & 0.3 & 0.04 & 2.8 & 24 & 1 & 7 \\
\hline 5 & 1.1-2.1 & 4.2 & 0.2 & 2.1 & 6.9 & 0.2 & 1.3 & & 0.3 & 0.05 & 4.2 & 36 & 2 & 10 \\
\hline 6 & $0.65-1.1$ & 2.2 & & 0.5 & 3.1 & 0.2 & 0.5 & & 0.14 & 0.05 & 2.0 & 17 & 1 & 3 \\
\hline 7 & $0.43-0.65$ & 1.9 & & & & & & & & & & & & \\
\hline BU & $0.43>$ & 1.0 & & & & & & & & & & & & \\
\hline Qingdao $n$ & 023: $2002 / 4$ & $1-4 / 4$, tot & flow $=12$ & $1 \mathrm{~m}^{3}$ & & & & & & & & & & \\
\hline 0 & $>11.0$ & 2.8 & 0.3 & 1.0 & 5.6 & 0.2 & 1.0 & & 0.2 & 0.04 & 3.6 & 26 & 1 & 5 \\
\hline 1 & $7.0-11.0$ & 1.6 & & 0.9 & 5.3 & 0.2 & 0.9 & & 0.2 & 0.04 & 3.3 & 27 & 2 & 5 \\
\hline 2 & $4.7-7.0$ & 3.7 & 0.4 & 1.5 & 7.0 & 0.2 & 1.3 & & 0.3 & 0.06 & 4.1 & 35 & 2 & 8 \\
\hline 3 & $3.3-4.7$ & 4.4 & 0.3 & 1.4 & 6.2 & 0.2 & 1.2 & 0.79 & 0.3 & 0.05 & 3.6 & 32 & 2 & 8 \\
\hline 4 & $2.1-3.3$ & 4.0 & 0.3 & 1.4 & 6.5 & 0.2 & 1.1 & 0.83 & 0.3 & 0.05 & 4.2 & 34 & 2 & 8 \\
\hline 5 & $1.1-2.1$ & 3.2 & & 0.8 & 4.4 & 0.2 & 0.7 & & 0.2 & 0.02 & 2.4 & 21 & 1 & 5 \\
\hline 6 & $0.65-1.1$ & 1.9 & & & 2.1 & 0.1 & & & 0.13 & 0.03 & 1.6 & 12 & 0.7 & 1 \\
\hline 7 & $0.43-0.65$ & & & & 0.9 & 0.06 & & & 0.06 & 0.03 & 0.8 & 6 & 0.4 & \\
\hline $\mathrm{BU}$ & $0.43>$ & & & & & & & & 0.04 & 0.04 & 1.5 & 7 & 0.7 & \\
\hline
\end{tabular}

Italic type indicates that the value is semiquantitative. 
Appendix. (continue)

\begin{tabular}{|c|c|c|c|c|c|c|c|c|c|c|c|c|c|c|c|}
\hline Stage & $\begin{array}{c}\text { size (um) } \\
(\mu \mathrm{m})\end{array}$ & $\begin{array}{c}\text { weight } \\
(\mathrm{mg})\end{array}$ & $\begin{array}{c}\mathrm{V} \\
\mathrm{ppm}\end{array}$ & $\begin{array}{c}\mathrm{Cr} \\
\mathrm{ppm}\end{array}$ & $\begin{array}{c}\text { Co } \\
\text { ppm }\end{array}$ & $\begin{array}{c}\mathrm{Ni} \\
\mathrm{ppm}\end{array}$ & $\begin{array}{c}\mathrm{Cu} \\
\mathrm{ppm}\end{array}$ & $\begin{array}{c}\mathrm{Zn} \\
\mathrm{ppm}\end{array}$ & $\begin{array}{c}\mathrm{Ga} \\
\mathrm{ppm}\end{array}$ & $\begin{array}{c}\mathrm{Rb} \\
\mathrm{ppm}\end{array}$ & $\begin{array}{c}\mathrm{Sr} \\
\mathrm{ppm}\end{array}$ & $\begin{array}{c}Y \\
\text { ppm }\end{array}$ & $\begin{array}{c}\mathrm{Zr} \\
\mathrm{ppm}\end{array}$ & $\begin{array}{c}\mathrm{Nb} \\
\mathrm{ppm}\end{array}$ & $\begin{array}{l}\text { Mo } \\
\text { ppm }\end{array}$ \\
\hline \multicolumn{16}{|c|}{ Beijing no.001: $2002 / 2 / 27-3 / 4$, total flow $=204 \mathrm{~m}^{3}$} \\
\hline$\frac{0}{0}$ & $>11.0$ & 5.6 & 240 & 59 & 14 & & 140 & 408 & 14 & 44 & 240 & 15 & 120 & 11 & 8 \\
\hline 1 & $7.0-11.0$ & 4.0 & 360 & & 15 & & 120 & 396 & 17 & 43 & 260 & 17 & 110 & 9 & \\
\hline 2 & $4.7-7.0$ & 6.4 & 230 & 59 & 20 & 33 & 120 & 854 & 22 & 47 & 330 & 20 & 140 & 11 & \\
\hline 3 & $3.3-4.7$ & 5.6 & 280 & & 19 & 13 & 130 & 1130 & 26 & 41 & 290 & 20 & 150 & 10 & \\
\hline 4 & $2.1-3.3$ & 3.4 & 850 & & 20 & 16 & 230 & 571 & 47 & 42 & 250 & 25 & 190 & 11 & 23 \\
\hline 5 & $1.1-2.1$ & 5.2 & 250 & & 8 & & 190 & 571 & 28 & 13 & 49 & 8 & 84 & 5 & 21 \\
\hline 6 & $0.65-1.1$ & 5.3 & 420 & & 3 & & 180 & 527 & 33 & 6 & 20 & 2 & 20 & 2 & \\
\hline 7 & $0.43-0.65$ & 2.4 & & & & & & & & & & & & & \\
\hline BU & $0.43>$ & 3.1 & & & & & & & & & & & & & \\
\hline Beijing no & $2: 2002 / 3 / 1$ & $-3 / 21$, to & flow $=\varepsilon$ & $1.5 \mathrm{~m}^{3}$ & & & & & & & & & & & \\
\hline$\frac{0}{0}$ & $>11.0$ & 15.4 & 120 & 100 & 25 & 69 & 76 & 180 & 29 & 140 & 250 & 31 & 200 & 22 & 8 \\
\hline 1 & $7.0-11.0$ & 24.8 & 37 & 24 & 6 & 17 & 23 & 46 & 7 & 34 & 53 & 8 & 50 & 6 & 1 \\
\hline 2 & $4.7-7.0$ & 16.7 & 77 & 130 & 17 & 110 & 60 & 130 & 17 & 80 & 120 & 16 & 110 & 11 & 2 \\
\hline 3 & $3.3-4.7$ & 13.1 & 58 & 43 & 12 & 33 & 48 & 100 & 14 & 59 & 83 & 13 & 91 & 10 & \\
\hline 4 & $2.1-3.3$ & $\begin{array}{l}8.4 \\
8.4\end{array}$ & 67 & & 7 & 21 & 49 & 130 & 9 & 42 & 53 & 10 & 59 & 6 & \\
\hline 5 & $1.1-2.1$ & 4.0 & 58 & & 15 & & 84 & 280 & 10 & 45 & 46 & 10 & 100 & 7 & 33 \\
\hline 6 & $0.65-1.1$ & 1.5 & & & 3 & & 200 & 290 & 13 & 39 & & 8 & 89 & 4 & 18 \\
\hline 7 & $0.43-0.65$ & 0.9 & & & & & & & & & & & & & \\
\hline $\mathrm{BU}$ & $0.43>$ & 1.3 & & & & & & & & & & & & & \\
\hline Beijing no & $3: 2002 / 4 / 8$ & $9: 30-21$ & , total $\mathrm{fl}$ & $w=1$ & $5 \mathrm{~m}^{3}$ & & & & & & & & & & \\
\hline 0 & $>11.0$ & 9.3 & 42 & 62 & 7 & 50 & 34 & 62 & 8 & 43 & 65 & 9 & 58 & 6 & \\
\hline 1 & $7.0-11.0$ & 5.1 & 69 & & 4 & 20 & 39 & 54 & 6 & 31 & 34 & 7 & 41 & 4 & \\
\hline 2 & $4.7-7.0$ & 4.2 & & & & & & & & & & & & & \\
\hline 3 & 3.3-4.7 & 2.3 & & & 10 & 71 & 90 & 113 & 13 & 69 & 56 & 14 & 91 & 7 & 71 \\
\hline 4 & $2.1-3.3$ & 2.6 & & & 3 & & 66 & 47 & 6 & 30 & 17 & 6 & 44 & 4 & 16 \\
\hline 5 & $1.1-2.1$ & 2.0 & 120 & & 3 & & 68 & 89 & 2 & 13 & & 1 & 12 & & \\
\hline 6 & $0.65-1.1$ & 0.6 & 390 & & 21 & & & & & 14 & & & & & \\
\hline 7 & $0.43-0.65$ & 1.3 & & & & & & & & & & & & & \\
\hline BU & $0.43>$ & 1.2 & & & & & & & & & & & & & \\
\hline Beijing no & $8: 2002 / 4 / 1$ & $-4 / 19$, to & flow $=\varepsilon$ & $1.5 \mathrm{~m}^{3}$ & & & & & & & & & & & \\
\hline 0 & $>11.0$ & 5.1 & 67 & & 9 & 120 & 91 & 160 & 10 & 45 & 130 & 10 & 65 & 7 & \\
\hline 1 & $7.0-11.0$ & 3.4 & 69 & 150 & 7 & 120 & 64 & 66 & 7 & 32 & 67 & 8 & 89 & 5 & 33 \\
\hline 2 & $4.7-7.0$ & $\begin{array}{l}4.4 \\
4.2\end{array}$ & 68 & 810 & 21 & 560 & 120 & 240 & 10 & 41 & 120 & 10 & 86 & 7 & 12 \\
\hline 3 & 3.3-4.7 & 3.3 & 71 & & & 22 & 75 & 150 & 5 & 23 & 51 & 5 & 49 & 3 & \\
\hline 4 & $2.1-3.3$ & 1.6 & 210 & 690 & 20 & 580 & 320 & 750 & 12 & 37 & 78 & 10 & 88 & 5 & \\
\hline 5 & $1.1-2.1$ & 1.0 & 650 & 1230 & 19 & 920 & 260 & 560 & 7 & 16 & & 2 & 57 & & \\
\hline 6 & $0.65-1.1$ & 1.2 & 320 & & & 43 & 250 & 520 & 8 & 5 & & & 18 & & \\
\hline 7 & $0.43-0.65$ & 1.8 & & & & & & & & & & & & & \\
\hline BU & $0.43>$ & 2.0 & & & & & & & & & & & & & \\
\hline Hefei no.C & 2002/3/30- & $/ 5$, total & $y=214$ & & & & & & & & & & & & \\
\hline 0 & $>11.0$ & 6.7 & 54 & 55 & 9 & 24 & 45 & 140 & 11 & 45 & 110 & 12 & 120 & 10 & 5 \\
\hline 1 & $7.0-11.0$ & 3.6 & 73 & 92 & 15 & 39 & 83 & 280 & 19 & 89 & 180 & 21 & 150 & 14 & \\
\hline 2 & $4.7-7.0$ & 9.7 & 53 & 42 & 10 & 23 & 39 & 190 & 12 & 53 & 100 & 13 & 80 & 8 & \\
\hline 3 & 3.3-4.7 & 9.8 & 55 & & & & & 310 & & & 110 & & & & \\
\hline 4 & $2.1-3.3$ & 4.6 & 110 & 60 & 14 & 36 & 84 & 810 & 21 & 86 & 120 & 19 & 120 & 11 & \\
\hline 5 & $1.1-2.1$ & 3.4 & & & & & & & & & & & & & \\
\hline 6 & $0.65-1.1$ & 5.3 & 45 & & 1 & 4 & 120 & 380 & 18 & 12 & 13 & 2 & 27 & 2 & \\
\hline 7 & $0.43-0.65$ & 3.0 & & & & & & & & & 11 & & & & \\
\hline BU & $0.43>$ & 7.9 & & & & & & & & & 7 & & & & \\
\hline Hefei no.C & $2002 / 4 / 12$ & $/ 19$, tota & $w=26$ & & & & & & & & & & & & \\
\hline 0 & $>11.0$ & 3.9 & 67 & & 8 & 17 & 46 & 120 & 10 & 49 & 110 & 12 & 140 & 10 & 6 \\
\hline 1 & $7.0-11.0$ & 2.4 & 59 & & 7 & 9 & 57 & 210 & 11 & 45 & 83 & 11 & 110 & 8 & \\
\hline 2 & $4.7-7.0$ & 4.1 & 80 & & 9 & 19 & 55 & 220 & 13 & 49 & 88 & 12 & 92 & 8 & \\
\hline 3 & 3.3-4.7 & 5.9 & 62 & & 8 & 33 & 43 & 210 & 12 & 47 & 66 & 11 & 89 & 8 & \\
\hline 4 & $2.1-3.3$ & 5.9 & 60 & & 6 & 14 & 37 & 240 & 12 & 43 & 54 & 10 & 81 & 6 & \\
\hline 5 & $1.1-2.1$ & 3.6 & 81 & & 5 & 8 & 71 & 290 & 17 & 45 & 47 & 9 & 140 & 8 & 8 \\
\hline 6 & $0.65-1.1$ & 4.0 & 51 & & 2 & & 86 & 250 & 14 & 16 & 16 & 3 & 51 & 3 & \\
\hline 7 & $0.43-0.65$ & 3.1 & 57 & & & & & & & & 10 & & & & \\
\hline BU & $0.43>$ & 1.6 & & & & & & & & & 18 & & & & \\
\hline Qingdao r & 022: $2002 / 3$ & 20-3/23, & al flow $=$ & $121 \mathrm{~m}$ & & & & & & & & & & & \\
\hline 0 & $>11.0$ & 0.0 & & & & & & & & & & & & & \\
\hline 1 & $7.0-11.0$ & 6.2 & 700 & 95 & 21 & 9 & 96 & & 27 & 130 & 200 & 29 & 150 & 17 & \\
\hline 2 & $4.7-7.0$ & 13.9 & 300 & 71 & 15 & 21 & 53 & & 19 & 82 & 140 & 17 & 110 & 11 & \\
\hline 3 & 3.3-4.7 & 12.9 & 390 & 80 & 16 & 18 & 52 & & 21 & 87 & 140 & 20 & 110 & 12 & \\
\hline 4 & $2.1-3.3$ & 15.2 & 250 & 37 & 8 & 4 & 34 & & 11 & 47 & 71 & 11 & 59 & 6 & \\
\hline 5 & $1.1-2.1$ & 4.2 & 530 & & 11 & & 81 & & 27 & 77 & 87 & 18 & 92 & 9 & \\
\hline 6 & $0.65-1.1$ & 2.2 & 1040 & & 4 & & 220 & & 60 & 36 & 40 & 7 & 73 & 8 & \\
\hline 7 & $0.43-0.65$ & 1.9 & & & & & & & & & & & & & \\
\hline BU & $0.43>$ & 1.0 & & & & & & & & & & & & & \\
\hline Qingdao r & 023: $2002 / 4$ & $1-4 / 4$, tot & low $=1$ & $1 \mathrm{~m}^{3}$ & & & & & & & & & & & \\
\hline 0 & $>11.0$ & 2.8 & 830 & & 13 & & 150 & & 12 & 58 & 110 & 14 & 65 & 8 & \\
\hline 1 & $7.0-11.0$ & 1.6 & 1980 & & 12 & & 190 & & 12 & 61 & 92 & 14 & 55 & 8 & \\
\hline 2 & $4.7-7.0$ & 3.7 & 940 & & 15 & 160 & & & 16 & 77 & 120 & 19 & 95 & 9 & \\
\hline 3 & 3.3-4.7 & $\begin{array}{l}.1 \\
4.4\end{array}$ & 760 & & 13 & & 110 & & 14 & 69 & 99 & 17 & 74 & 8 & \\
\hline 4 & $2.1-3.3$ & 4.0 & 460 & & 12 & & 88 & & 16 & 73 & 100 & 19 & 84 & 8 & \\
\hline 5 & $1.1-2.1$ & 3.2 & 720 & & 6 & & 79 & & 13 & 45 & 63 & 13 & 54 & 6 & \\
\hline 6 & $0.65-1.1$ & 1.9 & & & 3 & & 130 & & 14 & 24 & 37 & 7 & 69 & 11 & \\
\hline 7 & $0.43-0.65$ & 2.9 & & & & & & & & & 21 & & & 9 & \\
\hline BU & $0.43>$ & 2.4 & & & & & & & & & 34 & & & 5 & \\
\hline
\end{tabular}

Italic type indicates that the value is semiquantitative. 
Appendix. (continue)

\begin{tabular}{|c|c|c|c|c|c|c|c|c|c|c|c|c|c|c|c|}
\hline Stage & $\begin{array}{c}\text { size (um) } \\
(\mu \mathrm{m}) \\
\end{array}$ & $\begin{array}{c}\text { weight } \\
(\mathrm{mg})\end{array}$ & $\begin{array}{c}\mathrm{Cd} \\
\mathrm{ppm}\end{array}$ & $\begin{array}{c}\begin{array}{c}\mathrm{Sn} \\
\mathrm{ppm}\end{array} \\
\end{array}$ & $\begin{array}{c}\mathrm{Sb} \\
\mathrm{ppm}\end{array}$ & $\begin{array}{c}\text { Cs } \\
\mathrm{ppm}\end{array}$ & $\begin{array}{c}\mathrm{Ba} \\
\mathrm{ppm}\end{array}$ & $\begin{array}{c}\text { La } \\
\mathrm{ppm}\end{array}$ & $\begin{array}{c}\mathrm{Ce} \\
\mathrm{ppm}\end{array}$ & $\begin{array}{c}\mathrm{Pr} \\
\mathrm{ppm}\end{array}$ & $\begin{array}{c}\mathrm{Nd} \\
\mathrm{ppm}\end{array}$ & $\begin{array}{r}\mathrm{Sm} \\
\mathrm{ppm}\end{array}$ & $\begin{array}{c}\mathrm{Eu} \\
\mathrm{ppm}\end{array}$ & $\begin{array}{c}\mathrm{Gd} \\
\mathrm{ppm}\end{array}$ & $\begin{array}{r}\mathrm{Tb} \\
\mathrm{ppm} \\
\end{array}$ \\
\hline \multicolumn{16}{|c|}{ Beijing no.001: 2002/2/27-3/4, total flow $=204 \mathrm{~m}^{3}$} \\
\hline 0 & $>11.0$ & 5.6 & 2 & 30 & 6 & 3.1 & 550 & 19 & 41 & 4 & 15 & 3 & 0.7 & 3 & 0.4 \\
\hline 1 & $7.0-11.0$ & 4.0 & 3 & 20 & 7 & 3.3 & 570 & 22 & 45 & 5 & 16 & 3 & 0.7 & 3 & 0.6 \\
\hline 2 & $4.7-7.0$ & 6.4 & 5 & 20 & 10 & 3.6 & 670 & 26 & 56 & 5 & 19 & 4 & 0.8 & 3 & 0.6 \\
\hline 3 & 3.3-4.7 & 5.6 & 9 & 110 & 20 & 3.5 & 630 & 23 & 52 & 5 & 17 & 3 & 0.6 & 9 & 0.6 \\
\hline 4 & $2.1-3.3$ & 3.4 & 10 & 60 & 50 & 4.9 & 690 & 31 & 62 & 6 & 22 & 4 & 0.8 & 4 & 0.7 \\
\hline 5 & $1.1-2.1$ & 5.2 & 8 & 120 & 50 & 1.7 & 270 & 11 & 19 & 2 & 8 & 1 & 0.3 & 1 & 0.2 \\
\hline 6 & $0.65-1.1$ & 5.3 & 7 & 90 & 60 & 0.8 & 200 & 2 & 5 & 0.4 & 2 & 0.3 & 0.1 & 0.2 & 0.0 \\
\hline 7 & $0.43-0.65$ & 2.4 & 6 & & & & & & & & & & & & \\
\hline $\mathrm{BU}$ & $0.43>$ & 3.1 & 6 & & & & & & & & & & & & \\
\hline Beijing no & 02: $2002 / 3 / 1$ & $-3 / 21$, to & flow $=\varepsilon$ & $1.5 \mathrm{~m}^{3}$ & & & & & & & & & & & \\
\hline 0 & $>11.0$ & 15.4 & 1 & 10 & & 9.2 & 770 & 52 & 110 & 12 & 45 & 8 & 1.7 & 8 & 1.1 \\
\hline 1 & $7.0-11.0$ & 24.8 & 0.3 & 3 & 0.5 & 2.5 & 180 & 10 & 22 & 2 & 9 & 2 & 0.3 & 2 & 0.3 \\
\hline 2 & $4.7-7.0$ & 16.7 & 1 & 6 & & 5.7 & 420 & 22 & 53 & 5 & 20 & 4 & 0.8 & 4 & 0.6 \\
\hline 3 & $3.3-4.7$ & 13.1 & 2 & 6 & & 4.3 & 300 & 18 & 41 & 4 & 15 & 3 & 0.6 & 3 & 0.4 \\
\hline 4 & $2.1-3.3$ & 8.4 & 3 & 5 & 1 & 3.3 & 200 & 13 & 28 & 3 & 11 & 2 & 0.4 & 2 & 0.3 \\
\hline 5 & $1.1-2.1$ & 4.0 & 8 & 10 & 2 & 3.8 & 180 & 14 & 31 & 3 & 12 & 2 & 0.5 & 2 & 0.3 \\
\hline 6 & $0.65-1.1$ & 1.5 & 9 & 30 & & 3.8 & 100 & 10 & 21 & 2 & 9 & 2 & 0.3 & 2 & 0.2 \\
\hline 7 & $0.43-0.65$ & 0.9 & 11 & & & & & & & & & & & & \\
\hline $\mathrm{BU}$ & $0.43>$ & 1.3 & & & & & & & & & & & & & \\
\hline Beijing no & 03: $2002 / 4 / 8$ & $9: 30-21$ & , total $\mathrm{f}$ & $w=1$ & $5 \mathrm{~m}^{3}$ & & & & & & & & & & \\
\hline 0 & $>11.0$ & 9.3 & 1 & & 3 & 2.8 & 210 & 13 & 26 & 3 & 11 & 2 & 0.5 & 2 & 0.3 \\
\hline 1 & $7.0-11.0$ & 5.1 & 0.4 & & 6 & 2.2 & 120 & 8 & 16 & 2 & 7 & 1 & 0.3 & 1 & 0.2 \\
\hline 2 & $4.7-7.0$ & 4.2 & & & & 1.3 & & & & & & & & & \\
\hline 3 & $3.3-4.7$ & 2.3 & 0.7 & & 10 & 5.2 & 270 & 18 & 38 & 5 & 15 & 3 & 0.6 & 3 & 0.5 \\
\hline 4 & $2.1-3.3$ & 2.6 & 0.5 & 20 & 10 & 2.4 & 92 & 15 & 22 & 3 & 7 & 1 & 0.3 & 1 & 0.2 \\
\hline 5 & $1.1-2.1$ & 2.0 & 0.5 & & 20 & 1.0 & & 2 & 5 & 1 & 2 & 0.5 & 0.1 & & 0.1 \\
\hline 6 & $0.65-1.1$ & 0.6 & 2 & & 30 & 1.4 & & & 5 & 1 & & 0.7 & & & \\
\hline 7 & $0.43-0.65$ & 1.3 & & & & & & & & & & & & & \\
\hline BU & $0.43>$ & 1.2 & & & & & & & & & & & & & \\
\hline Beijing no & 08: $2002 / 4 / 1$ & $-4 / 19$, to & flow $=\varepsilon$ & $1.5 \mathrm{~m}^{3}$ & & & & & & & & & & & \\
\hline 0 & $>11.0$ & 5.1 & 1 & 30 & 5 & 2.7 & 340 & 16 & 32 & 4 & 13 & 2 & 0.5 & 2 & 0.4 \\
\hline 1 & $7.0-11.0$ & 3.4 & 1 & & 8 & 2.3 & 200 & 10 & 22 & 2 & 9 & 2 & 0.4 & 2 & 0.3 \\
\hline 2 & $4.7-7.0$ & 4.2 & 2 & 30 & & 2.9 & 360 & 14 & 30 & 3 & 12 & 2 & 0.4 & 2 & 0.3 \\
\hline 3 & $3.3-4.7$ & 3.3 & 1 & 10 & 4 & 1.7 & 200 & 8 & 16 & 2 & 7 & 1 & 0.2 & 1 & 0.2 \\
\hline 4 & $2.1-3.3$ & 1.6 & 7 & 40 & & 3.3 & 340 & 14 & 29 & 4 & 12 & 2 & 0.4 & 2 & 0.3 \\
\hline 5 & $1.1-2.1$ & 1.0 & 6 & 90 & 9 & 2.5 & & 6 & 12 & 2 & 5 & 1 & & & \\
\hline 6 & $0.65-1.1$ & 1.2 & 5 & 150 & & 1.4 & & 2 & 4 & 0.5 & 2 & & & & \\
\hline 7 & $0.43-0.65$ & 1.8 & 7 & & & & & & & & & & & & \\
\hline BU & $0.43>$ & 2.0 & 5 & & & & & & & & & & & & \\
\hline Hefei no.C & $2002 / 3 / 30-$ & 15, total & $N=214$ & & & & & & & & & & & & \\
\hline 0 & $>11.0$ & 6.7 & 1 & 9 & & 3.1 & 270 & 16 & 32 & 3 & 14 & 2 & 0.5 & 2 & 0.3 \\
\hline 1 & $7.0-11.0$ & 3.6 & 2 & 20 & & 7.2 & 470 & 30 & 62 & 7 & 25 & 5 & 1.0 & 4 & 0.7 \\
\hline 2 & $4.7-7.0$ & 9.7 & 2 & 10 & & 4.3 & 280 & 18 & 38 & 4 & 15 & 3 & 0.6 & 3 & 0.4 \\
\hline 3 & $3.3-4.7$ & 9.8 & & & & & 320 & & & & & & & & \\
\hline 4 & $2.1-3.3$ & 4.6 & 9 & 30 & & 9.1 & 460 & 29 & 65 & 6 & 24 & 4 & 0.9 & 4 & 0.6 \\
\hline 5 & $1.1-2.1$ & 3.4 & & & & & & & & & & & & & \\
\hline 6 & $0.65-1.1$ & 5.3 & 6 & 80 & & 2.6 & 79 & 4 & 8 & 1 & 3 & 0.5 & 0.1 & 0.4 & 0.1 \\
\hline 7 & $0.43-0.65$ & 3.0 & 9 & & & & & & & & & & & & \\
\hline $\mathrm{BU}$ & $0.43>$ & 7.9 & 4 & & & & & & & & & & & & \\
\hline Hefei no.C & $2002 / 4 / 12-$ & $\mid 19$, tota & $\mathrm{ow}=26$ & $\mathrm{~m}^{3}$ & & & & & & & & & & & \\
\hline 0 & $>11.0$ & 3.9 & 1 & 10 & & 3.3 & 290 & 19 & 38 & 4 & 15 & 3 & 0.5 & 2 & 0.4 \\
\hline 1 & $7.0-11.0$ & 2.4 & 5 & 20 & & 3.8 & 280 & 17 & 35 & 3 & 14 & 2 & 0.5 & 2 & 0.4 \\
\hline 2 & $4.7-7.0$ & 4.1 & 4 & 20 & & 4.1 & 290 & 17 & 37 & 4 & 14 & 3 & 0.4 & 2 & 0.4 \\
\hline 3 & 3.3-4.7 & 5.9 & 4 & 10 & & 4.1 & 260 & 16 & 36 & 4 & 13 & 2 & 0.5 & 2 & 0.4 \\
\hline 4 & $2.1-3.3$ & 5.9 & 6 & 20 & & 4.6 & 230 & 15 & 34 & 3 & 12 & 2 & 0.5 & 2 & 0.3 \\
\hline 5 & $1.1-2.1$ & 3.6 & 8 & 50 & & 6.9 & 200 & 14 & 31 & 3 & 10 & 2 & 0.3 & 2 & 0.3 \\
\hline 6 & $0.65-1.1$ & 4.0 & 10 & 60 & & 2.7 & 78 & 5 & 10 & 1 & 3 & 0.6 & 0.1 & 0.5 & 0.1 \\
\hline 7 & $0.43-0.65$ & 3.1 & 9 & & & & & & & & & & & & \\
\hline BU & $0.43>$ & 1.6 & 8 & & & & & & & & & & & & \\
\hline Qingdao r & $022: 2002 / 3$ & $20-3 / 23$ & al flow = & $121 \mathrm{~m}$ & & & & & & & & & & & \\
\hline 0 & $>11.0$ & 0.0 & & & & & & & & & & & & & \\
\hline 1 & $7.0-11.0$ & 6.2 & 1 & 10 & 1 & 9.3 & 740 & 42 & 90 & 9 & 36 & 7 & 1.3 & 6 & 1.0 \\
\hline 2 & 4.7-7.0 & 13.9 & 0.7 & 8 & 3 & 5.9 & 500 & 26 & 60 & 6 & 23 & 4 & 0.9 & 4 & 0.6 \\
\hline 3 & $3.3-4.7$ & 12.9 & 1 & 20 & 3 & 6.7 & 490 & 29 & 67 & 7 & 25 & 5 & 1.0 & 4 & 0.7 \\
\hline 4 & $2.1-3.3$ & 15.2 & 1 & 7 & 3 & 3.9 & 260 & 15 & 34 & 3 & 13 & 3 & 0.5 & 2 & 0.4 \\
\hline 5 & $1.1-2.1$ & 4.2 & 4 & 40 & 20 & 10.3 & 380 & 24 & 53 & 5 & 20 & 4 & 0.7 & 3 & 0.6 \\
\hline 6 & $0.65-1.1$ & 2.2 & 4 & 90 & 40 & 7.5 & 200 & 10 & 21 & 2 & 8 & 2 & 0.3 & 1 & 0.3 \\
\hline 7 & $0.43-0.65$ & 1.9 & & & & & & & & & & & & & \\
\hline BU & $0.43>$ & 1.0 & & & & & & & & & & & & & \\
\hline Qingdao $r$ & $023: 2002 / 4$ & $1-4 / 4$, tot & flow $=1$ & $1 \mathrm{~m}^{3}$ & & & & & & & & & & & \\
\hline 0 & $>11.0$ & 2.8 & 1 & 40 & & 3.6 & 650 & 21 & 42 & 5 & 17 & 3 & 0.7 & 3 & 0.5 \\
\hline 1 & $7.0-11.0$ & 1.6 & 0.6 & & & 4.1 & 520 & 20 & 41 & 5 & 17 & 3 & 0.7 & 3 & 0.4 \\
\hline 2 & $4.7-7.0$ & 3.7 & 1 & 20 & 0.6 & 5.2 & 550 & 30 & 64 & 7 & 26 & 5 & 0.8 & 4 & 0.7 \\
\hline 3 & $3.3-4.7$ & 4.4 & 1 & 20 & 30 & 4.7 & 430 & 24 & 50 & 5 & 20 & 3 & 0.7 & 3 & 0.5 \\
\hline 4 & $2.1-3.3$ & 4.0 & 2 & 20 & 20 & 5.4 & 440 & 26 & 55 & 6 & 21 & 4 & 0.9 & 4 & 0.6 \\
\hline 5 & $1.1-2.1$ & 3.2 & 2 & 20 & 4 & 3.9 & 310 & 18 & 37 & 4 & 14 & 3 & 0.6 & 3 & 0.4 \\
\hline 6 & $0.65-1.1$ & 1.9 & 4 & 40 & 20 & 3.0 & 250 & 11 & 21 & 2 & 7 & 1 & 0.3 & 1 & 0.2 \\
\hline 7 & $0.43-0.65$ & 2.9 & 6 & & & & & & & & & & & & \\
\hline $\mathrm{BU}$ & $0.43>$ & 2.4 & 4 & & & & & & & & & & & & \\
\hline
\end{tabular}

Italic type indicates that the value is semiquantitative. 
Appendix. (continue)

\begin{tabular}{|c|c|c|c|c|c|c|c|c|c|c|c|c|c|c|c|}
\hline Stage & $\begin{array}{c}\text { size (um) } \\
(\mu \mathrm{m})\end{array}$ & $\begin{array}{c}\text { weight } \\
(\mathrm{mg})\end{array}$ & $\begin{array}{r}\text { Dy } \\
\text { ppm }\end{array}$ & $\begin{array}{c}\mathrm{Ho} \\
\mathrm{ppm}\end{array}$ & $\begin{array}{c}\mathrm{Er} \\
\mathrm{ppm}\end{array}$ & $\begin{array}{c}\mathrm{Tm} \\
\mathrm{ppm} \\
\end{array}$ & $\begin{array}{r}\mathrm{Yb} \\
\mathrm{ppm} \\
\end{array}$ & $\begin{array}{r}\mathrm{Lu} \\
\mathrm{ppm}\end{array}$ & $\begin{array}{c}\mathrm{Hf} \\
\mathrm{ppm}\end{array}$ & $\begin{array}{c}\mathrm{Ta} \\
\mathrm{ppm}\end{array}$ & $\begin{array}{c}\mathrm{TI} \\
\mathrm{ppm}\end{array}$ & $\begin{array}{r}\mathrm{Pb} \\
\mathrm{ppm}\end{array}$ & $\begin{array}{c}\mathrm{Bi} \\
\mathrm{ppm}\end{array}$ & $\begin{array}{c}\text { Th } \\
\mathrm{ppm} \\
\end{array}$ & $\begin{array}{r}\mathrm{U} \\
\mathrm{ppm}\end{array}$ \\
\hline \multicolumn{16}{|c|}{ Beijing no.001: $2002 / 2 / 27-3 / 4$, total flow $=204 \mathrm{~m}^{3}$} \\
\hline 0 & $>11.0$ & 5.6 & 2 & 0.4 & 1 & 0.2 & 1 & 0.2 & 2 & 3 & 2 & 240 & 2 & 7 & 2 \\
\hline 1 & $7.0-11.0$ & 4.0 & 2 & 0.4 & 1 & 0.2 & 1 & 0.2 & 2 & 3 & 3 & 250 & 4 & 7 & 3 \\
\hline 2 & $4.7-7.0$ & 6.4 & 3 & 0.5 & 2 & 0.3 & 2 & 0.3 & 3 & 2 & 4 & 300 & 4 & 8 & 3 \\
\hline 3 & $3.3-4.7$ & 5.6 & 3 & 0.5 & 2 & 0.3 & 2 & 0.2 & 3 & 4 & 5 & 480 & 7 & 8 & 4 \\
\hline 4 & $2.1-3.3$ & 3.4 & 3 & 0.7 & 2 & 0.4 & 2 & 0.3 & 4 & 4 & 6 & 1400 & 20 & 10 & 4 \\
\hline 5 & $1.1-2.1$ & 5.2 & 1 & 0.2 & 0.7 & 0.1 & 1 & 0.1 & 2 & 4 & 2 & 1650 & 20 & 4 & 1 \\
\hline 6 & $0.65-1.1$ & 5.3 & 0.2 & 0.1 & 0.2 & 0.0 & 0.2 & 0.0 & 0.3 & 5 & 2 & 1830 & 20 & 1 & 1 \\
\hline 7 & $0.43-0.65$ & 2.4 & & & & & & & & & & 2810 & & & \\
\hline BU & $0.43>$ & 3.1 & & & & & & & & & & 3560 & & & \\
\hline Beijing no & 02: $2002 / 3 / 1$ & $-3 / 21$, to & flow $=8$ & $1.5 \mathrm{~m}^{3}$ & & & & & & & & & & & \\
\hline 0 & $>11.0$ & 15.4 & 5 & 1.0 & 3 & 0.4 & 3 & 0.4 & 5 & 2 & 1 & 100 & 1 & 20 & 4 \\
\hline 1 & $7.0-11.0$ & 24.8 & 1 & 0.2 & 0.7 & 0.1 & 0.7 & 0.1 & 1 & 1 & 0.3 & 30 & 0.4 & 4 & 1 \\
\hline 2 & $4.7-7.0$ & 16.7 & 3 & 0.5 & 2 & 0.2 & 1 & 0.2 & 3 & 2 & 1 & 70 & 1 & 8 & 2 \\
\hline 3 & $3.3-4.7$ & 13.1 & 2 & 0.4 & 1 & 0.2 & 1 & 0.2 & 2 & 2 & 0.7 & 60 & 1 & 6 & 2 \\
\hline 4 & $2.1-3.3$ & 8.4 & 2 & 0.3 & 1 & 0.1 & 1 & 0.1 & 2 & 2 & 0.5 & 70 & 1 & 5 & 1 \\
\hline 5 & $1.1-2.1$ & 4.0 & 2 & 0.3 & 1 & 0.1 & 1 & 0.1 & & 3 & 1 & 200 & 3 & 8 & 1 \\
\hline 6 & $0.65-1.1$ & 1.5 & 1 & 0.2 & 0.6 & 0.1 & 0.7 & 0.1 & & 10 & 2 & 740 & 7 & & \\
\hline 7 & $0.43-0.65$ & 0.9 & & & & & & & & & & 1660 & & & \\
\hline BU & $0.43>$ & 1.3 & & & & & & & & & & & & & \\
\hline Beijing no & 03: $2002 / 4 / 8$ & $9: 30-21$ & , total $\mathrm{fl}$ & $w=1$. & $5 \mathrm{~m}^{3}$ & & & & & & & & & & \\
\hline 0 & $>11.0$ & 9.3 & 2 & 0.3 & 1 & 0.1 & 1 & 0.1 & 1 & 3 & 0.3 & 30 & 0.3 & 4 & 1 \\
\hline 1 & $7.0-11.0$ & 5.1 & 1 & 0.2 & 1 & 0.1 & 0.5 & 0.1 & 1 & 2 & 0.2 & 30 & 0.5 & 3 & 0.6 \\
\hline 2 & $4.7-7.0$ & 4.2 & & & & & & & & 3 & & & & & \\
\hline 3 & $3.3-4.7$ & 2.3 & 2 & 0.5 & 1 & 0.2 & 1 & 0.3 & 2 & 6 & 0.5 & 60 & 0.7 & 7 & 1 \\
\hline 4 & $2.1-3.3$ & 2.6 & 1 & 0.2 & 0.6 & 0.1 & 0.4 & 0.1 & 1 & 2 & 0.2 & 40 & 1 & 4 & 0.6 \\
\hline 5 & $1.1-2.1$ & 2.0 & 0.2 & & 2 & 0.0 & & 0.03 & & 1 & & 30 & 0.2 & 2 & 0.2 \\
\hline 6 & $0.65-1.1$ & 0.6 & & & & & & & & 8 & & 180 & 1 & 4 & \\
\hline 7 & $0.43-0.65$ & 1.3 & & & & & & & & & & 250 & & & \\
\hline$B U$ & $0.43>$ & 1.2 & & & & & & & & & & 220 & & & \\
\hline Beijing no & 08: $2002 / 4 / 1$ & $-4 / 19$, to & flow $=8$ & $1.5 \mathrm{~m}^{3}$ & & & & & & & & & & & \\
\hline 0 & $>11.0$ & 5.1 & 2 & 0.3 & 1 & 0.1 & 1 & 0.1 & 2 & 3 & 0.6 & 90 & 0.5 & 5 & 1 \\
\hline 1 & $7.0-11.0$ & 3.4 & 1 & 0.2 & 0.7 & 0.1 & 0.6 & 0.1 & 2 & 3 & 0.5 & 80 & 0.6 & 6 & 1 \\
\hline 2 & $4.7-7.0$ & 4.2 & 2 & 0.3 & 1 & 0.2 & 1 & 0.1 & 2 & 4 & 1 & 130 & 1 & 6 & 1 \\
\hline 3 & $3.3-4.7$ & 3.3 & 1 & 0.2 & 0.6 & 0.1 & 0.4 & 0.1 & 1 & 5 & 1 & 120 & 1 & 4 & 1 \\
\hline 4 & $2.1-3.3$ & 1.6 & 1 & 0.3 & 1 & 0.1 & 0.7 & 0.2 & 2 & 3 & 3 & 600 & 6 & 6 & 2 \\
\hline 5 & $1.1-2.1$ & 1.0 & 0.6 & & 0.3 & & & 0.04 & 2 & 20 & 4 & 1430 & 10 & 4 & 0.7 \\
\hline 6 & $0.65-1.1$ & 1.2 & & & & & & & & & 4 & 1740 & 20 & 2 & 0.3 \\
\hline 7 & $0.43-0.65$ & 1.8 & & & & & & & & & & 1200 & & & \\
\hline BU & $0.43>$ & 2.0 & & & & & & & & & & 1400 & & & \\
\hline Hefei no.0 & $2002 / 3 / 30$ & 15, total f & $v=214$ & & & & & & & & & & & & \\
\hline 0 & $>11.0$ & 6.7 & 2 & 0.4 & 1 & 0.1 & 1 & 0.1 & 3 & 3 & 1 & 100 & 2 & 6 & 2 \\
\hline 1 & $7.0-11.0$ & 3.6 & 4 & 0.6 & 2 & 0.3 & 2 & 0.2 & 4 & 4 & 1 & 240 & 4 & 10 & 3 \\
\hline 2 & $4.7-7.0$ & 9.7 & 2 & 0.4 & 1 & 0.2 & 1 & 0.2 & 2 & 2 & 1 & 160 & 3 & 6 & 2 \\
\hline 3 & $3.3-4.7$ & 9.8 & & & & & & & & & & & & & \\
\hline 4 & $2.1-3.3$ & 4.6 & 3 & 0.6 & 2 & 0.3 & 2 & 0.3 & 3 & 5 & 2 & 920 & 20 & 10 & 3 \\
\hline 5 & $1.1-2.1$ & 3.4 & & & & & & & & & & & & & \\
\hline 6 & $0.65-1.1$ & 5.3 & 0.4 & 0.1 & 0.2 & 0.0 & 0.3 & 0.02 & 0.6 & 4 & 2 & 2380 & 50 & 2 & 0.7 \\
\hline 7 & $0.43-0.65$ & 3.0 & & & & & & & & & & 2770 & & & \\
\hline BU & $0.43>$ & 7.9 & & & & & & & & & & 600 & & & \\
\hline Hefei no.0 & $2002 / 4 / 12$ & $/ 19$, total & $w=26$ & $\mathrm{~m}^{3}$ & & & & & & & & & & & \\
\hline 0 & $>11.0$ & 3.9 & 2 & 0.4 & 1 & 0.2 & 1 & 0.1 & 3 & 3 & 0.5 & 120 & 2 & 7 & 2 \\
\hline 1 & $7.0-11.0$ & 2.4 & 2 & 0.3 & 1 & 0.1 & 1 & 0.1 & 2 & 3 & 0.6 & 220 & 4 & 6 & 2 \\
\hline 2 & $4.7-7.0$ & 4.1 & 2 & 0.4 & 1 & 0.1 & 1 & 0.2 & 2 & 4 & 1 & 240 & 5 & 6 & 2 \\
\hline 3 & $3.3-4.7$ & 5.9 & 2 & 0.4 & 1 & 0.2 & 1 & 0.1 & 2 & 3 & 0.7 & 240 & 5 & 6 & 2 \\
\hline 4 & $2.1-3.3$ & 5.9 & 2 & 0.3 & 1 & 0.2 & 1 & 0.1 & 2 & 4 & 1 & 480 & 10 & 5 & 2 \\
\hline 5 & $1.1-2.1$ & 3.6 & 1 & 0.3 & 1 & 0.1 & 1 & 0.1 & 3 & 5 & 2 & 1850 & 40 & 6 & 2 \\
\hline 6 & $0.65-1.1$ & 4.0 & 0.4 & 0.1 & 0.3 & 0.0 & 0.3 & 0.1 & 1 & 4 & 2 & 2510 & 50 & 2 & 0.7 \\
\hline 7 & $0.43-0.65$ & 3.1 & & & & & & & & & & 2530 & & & \\
\hline BU & $0.43>$ & 1.6 & & & & & & & & & & 1690 & & & \\
\hline Qingdao $\mathrm{n}$ & $022: 2002 / 3$ & $20-3 / 23$ & al flow $=$ & $121 \mathrm{~m}$ & & & & & & & & & & & \\
\hline 0 & $>11.0$ & 0.0 & & & & & & & & & & & & & \\
\hline 1 & $7.0-11.0$ & 6.2 & 5 & 0.9 & 3 & 0.4 & 3 & 0.4 & 4 & 4 & 1 & 150 & 2 & 10 & 4 \\
\hline 2 & $4.7-7.0$ & 13.9 & 3 & 0.6 & 2 & 0.3 & 2 & 0.2 & 3 & 2 & 1 & 110 & 1 & 9 & 3 \\
\hline 3 & $3.3-4.7$ & 12.9 & 3 & 0.7 & 2 & 0.3 & 2 & 0.2 & 3 & 2 & 1 & 150 & 2 & 10 & 3 \\
\hline 4 & $2.1-3.3$ & 15.2 & 2 & 0.4 & 1 & 0.2 & 1 & 0.1 & 2 & 2 & 0.6 & 160 & 2 & 5 & 2 \\
\hline 5 & $1.1-2.1$ & 4.2 & 3 & 0.6 & 2 & 0.3 & 2 & 0.2 & 2 & 5 & & 1380 & 20 & 8 & 3 \\
\hline 6 & $0.65-1.1$ & 2.2 & 1 & 0.2 & 0.7 & 0.1 & 0.7 & 0.1 & 2 & 10 & & 3960 & 50 & 3 & 2 \\
\hline 7 & $0.43-0.65$ & 1.9 & & & & & & & & & & & & & \\
\hline$B U$ & $0.43>$ & 1.0 & & & & & & & & & & & & & \\
\hline Qingdao n & $023: 2002 / 4$ & $1-4 / 4$, tot & low $=1$ & $1 \mathrm{~m}^{3}$ & & & & & & & & & & & \\
\hline 0 & $>11.0$ & 2.8 & 2 & 0.5 & 1 & 0.2 & 1 & 0.2 & 1 & 8 & 0.5 & 150 & 1 & 5 & 2 \\
\hline 1 & $7.0-11.0$ & 1.6 & 2 & 0.4 & 1 & 0.2 & 1 & 0.1 & 1 & 10 & 0.5 & 230 & 1 & 5 & 2 \\
\hline 2 & $4.7-7.0$ & 3.7 & 3 & 0.6 & 2 & 0.2 & 2 & 0.2 & 2 & 4 & 0.7 & 220 & 2 & 8 & 2 \\
\hline 3 & $3.3-4.7$ & 4.4 & 3 & 0.5 & 1 & 0.2 & 2 & 0.2 & 2 & 5 & 0.7 & 160 & 2 & 7 & 2 \\
\hline 4 & $2.1-3.3$ & 4.0 & 3 & 0.6 & 2 & 0.2 & 2 & 0.2 & 2 & 5 & 1 & 200 & 2 & 7 & 2 \\
\hline 5 & $1.1-2.1$ & 3.2 & 2 & 0.4 & 1 & 0.2 & 1 & 0.2 & 1 & 8 & 1 & 420 & 7 & 5 & 2 \\
\hline 6 & $0.65-1.1$ & 1.9 & 1 & 0.2 & 0.4 & 0.1 & 1 & 0.1 & 2 & 10 & 1 & 1650 & 20 & 2 & 1 \\
\hline 7 & $0.43-0.65$ & 2.9 & & & & & & & & & & 1390 & & & \\
\hline BU & $0.43>$ & 2.4 & & & & & & & & & & 1030 & & & \\
\hline
\end{tabular}

Italic type indicates that the value is semiquantitative. 